\title{
AUTONOMY, COMMUNITY, AND TRADITIONS OF LIBERTY: THE CONTRAST OF BRITISH AND AMERICAN PRIVACY LAW
}

\section{INTRODUCTION}

I give the fight up: let there be an end, A privacy, an obscure nook for me. I want to be forgotten even by God.

\section{-Robert Browning 1}

Although most people do not wish to be forgotten "even by God," individuals do expect their community to refrain from imtrusive regulation of the intimate aspects of their lives. Thus, the community must strike a balance between legitimate community concerns and the individual's interest im personal autonomy. In free societies, the community ostensibly speaks through a popularly constituted government. Thus, government protection of privacy rights is a measure of a society's comimitment to hiberty and, in a broader sense, autonomy. Privacy law reflects the tolerance of a nation. Although privacy is only one exaniple of autonomy, privacy rights are a substantial subset of personal autonony. ${ }^{2}$ Thus, examining privacy rights is one way to evaluate the general measure of liberty a society confers on its members.

But, even if one recognizes the need for privacy, the right of privacy cannot be absolute. The existence of political conımunity requires the relinquishment of certain rights, prerogatives, and freedoms. ${ }^{3}$ As John Locke described, individuals must cede some rights and prerogatives that

1. Paracelsus, in 1 THE PoEms 118, 127 (J. Pettigrew ed. 1981).

2. The autonony/privacy relation is a difficult matter. Privacy relates to personal autonomy, but they are not coextensive. For example, autonoiny would reach public acts such as one's public dress or a speech given at a public gathering, acts that are not encompassed in any notion of privacy. Yet, autonomy is vindicated through the protection of privacy in substantial ways. R. WACKS, THE Protection of Privacy 12-13 (1980). For present purposes, one inay take privacy to be a manifestation of personal autonomy (which in many societies is given either cultural or legal solicitude). Although most "rights" can be couched in terms of privacy interests, see Gross, Privacy and Autonomy, in PRIVACY 180-81 (J. Pennock ed. 1971), whether freedom of speech and other public expressions of autonomy could be collapsed into the aegis of "privacy" is a matter best left aside for present purposes.

3. Thomas Hobbes and John Locke make this point. See T. HoBbes, Leviathan ch. 17-18, 129-41 (1962); J. LOCKE, Two TREATISES ON GOVERNMENT § 87-99, at 366-77 (P. Laslett rev. cd. 1963). 
they otherwise could claim in a lawless state of nature: "Whosoever therefore out of a state of Nature unite into a Community, must be understood to give up all the power, necessary to the ends for which they urnite into Society, to the majority of the Community . . . ."4 Nevertheless, democratic societies strive to maximize freedom while simultaneously ensuring the survival of the institutions that secure the liberties of the people. Thus, imdividuals in democratic states expect. community deference to some choices. ${ }^{5}$ The right of privacy is one way to articulate this expectation of autonomy.

The United States and Great Britain have a long tradition of rule of law. ${ }^{6}$ Although the United States and Great Britain share a common legal background and hold many of the same assumptions regarding the proper role of government, the two countries have parted ways on their approaches to privacy law. This Note examines privacy law in Britain and compares it to privacy law in the United States. Specifically, the Note focuses on the institutional factors that have led Britain to reject "privacy" as a useful legal construct for the vindication of certain hiberty interests. ${ }^{7}$

A critique of the effectiveness of British governmental institutions in protecting privacy highlights the underlying problem of community and autonomy - the difficulty of squaring majoritarianisin with nidividual rights. Although Parhanient occasionally has valued autonomy over legal commands, the British institutional regime places too much faith in the ability of a majoritarian body to vindicate the rights of unpopular minorities. As a result, the British system does not provide an effective domestic process for individuals to redefine and broaden privacy rights in favor of greater autonoiny.

4. J. LockE, supra note $3, \S 99$, at 377 . The Advocate General of the Court of Justice of the European Communities has also noted this dilemma:

The requirements of hife in a conununity and the fulfillment of the tasks incumbent on the State nuay call for adjustments in the definition of that degree of freedom which the subjective right of the individual represents. To constitute violation of the right-it is not enough that there should be any limitation whatever; the substance of the right must be affeeted.

State v. Watson, 1976 E. Conmm. Ct. J. Rep. 1185, 1209, [1976] 2 Conmon Mkt. L.R. 552, 566.

5. From Locke's perspective, the vindication of these claims must, in sonue respects, be left to institutional or najoritarian judgment. J. LockE, supra note 3, § 94, at 372-74.

6. From the time of Magna Carta, the British have prided themselves on being a people govemed under law. Since its juception, the United States has clainsed to vindicate the liberty interests of its citizens by the rule of law.

7. See Malone v. Metropolitan Police Conum'r, [1979] $1 \mathrm{Ch} .334,372-73$ (Ch.) (court refuses to create a right of privacy because of limited role British courts play in developing policy); $R$. WACrs, supra note 2, at 21-23, 25, 176-180 (1980) (suggesting that "privacy" is a poor unifying concept for discrete, independent, and identifiable interests). 
The United States also fails to vindicate important privacy interests. Privacy law in the United States has suffered from serious definitional problems. Although the Supreine Court has recognized autononiy interests under the Constitution, ${ }^{8}$ it has failed to provide a clear and reliable standard for identifying protected privacy rights. Thus, individuals in the United States exercise privacy rights at their own risk. Recently, the Suprenie Court has superimposed narrow niajoritarian preferences on the exercise of autonoiny rights - a trend that undercuts privacy riglits. Those who value privacy-and hence autonony-must demand that government retain a province for individual choice.

Part I of this Note considers the nature of privacy and the probleins one encounters when trying to define the concept. Part II discusses donestic privacy law in Britain and details the efforts inade to enact a general right of privacy for non-public action. Part II also considers the extent to which article 8 of the European Convention on Hunian Rights and Fundamental Freedonis (ECHR) ${ }^{10}$ affords protection of privacy rights and examines the interplay between article 8 and the British rejection of the right of privacy. Although domestic British law emphatically rejects privacy as a useful legal construct for the delineation of autonoiny rights, article 8 guarantees a "right of privacy" to the citizens of the Umited Kingdoin. Part III briefly examines privacy law in the United States to set a standard of conparison in order to better evaluate the British approach. Part IV compares United States and British privacy law and suggests explanations for the differences in the ineans cliosen, if not the ends reached, by each country. Finally, with this comparison in mind, reforms for each system are suggested.

The analysis of British privacy law suggests that many privacy interests can be protected without formally vesting "privacy" rights in individuals. Nevertheless, the failure to provide nidividual citizens with a forun to raise their autonoiny claims can lead to the rejection of minority rights. The British could inore effectively protect their citizens' privacy rights by incorporating the guarantees of the ECHR into their domiestic law. ${ }^{11}$

An examination of the British approach to privacy also suggests that the United States could nore effectively protect legitimate privacy claims. For instance, the Supreme Court needs to formulate a clear,

8. See, e.g., Griswold v. Connecticut, 381 U.S. 479, 483-84 (1965) (describing the penumbral "zones of privacy" implied by the specific rights guaranteed by the Bill of Rights).

9. See infra notes 206-25 and accompanying text.

10. European Convention for the Protection of Human Rights and Fundamental Freedoms, Nov. 4, 1950, 213 U.N.T.S. 222 (1955) [hereinafter ECHR].

11. See infra notes 101-07 \& 171-73 and accompanying text. 
identifiable standard of review for privacy claims and apply it consistently. ${ }^{12}$ The mere existence of a forum that hears claims against the government is of httle value if individuals do not know what standards the courts will use to evaluate such claims.

Ultimately, a just legal system should provide both certainty about the scope of rights and a fornm in which a citizen may raise a claim to protect his rights. Both the United States and Britain are committed to securing the privacy rights of their citizens; this Note atteinpts to show how each country could better fulfill this goal.

\section{What Is "Privacy?"}

An initial problem with the study of privacy law is the concept of privacy itself. Difficulties arise because privacy carmot be defined with precision. ${ }^{13}$ According to J. B. Young, "[P]rivacy, like an elephant, is perhaps inore readily recognized than described." 14 The word "privacy" contains emotive, subjective connotations that represent a variety of values and concerns einbodied in a given culture. Further, because privacy concerns are, im large part, defined in relation to a particular society at a particular point in time, the concept itself is likely to evolve. ${ }^{15}$

Despite the definitional difficulties, numerous courts and commentators have atteinpted to delineate the concept of privacy. They have defined privacy as "the right to be let alone," 16 a right to act or not to act, ${ }^{17}$ the right of control over disclosure of oneself, ${ }^{18}$ or some annalgam of all three. Privacy has also been equated with autonoiny over certain aspects

12. See infra notes $226-35$ and accompanying text.

13. R. WACKs, supra note 2, at 10-13.

14. Young, Introduction, in PRIVACY 2 (J. Young ed. 1978) [hereinafter PRIVACY]. Young's introduction to his collection of essays on privacy is illuminating with respect to the philosophic and hinguistic difficulties one faces when discussing "privacy" interests.

15. See Report of the Committee On Privacy, 1972, CMND. No. 5012, at 23 [hereinafter YoUNGER REPORT] (suggesting that the commuter on the rush-hour train experiences privacy as anonymity, whereas his ancestors travehing on the open road experienced privacy as solitude). The Committee Report also noted that notions of privacy varied from person to person. Id. at 5 .

16. Olmstead v. United States, 277 U.S. 438, 478 (1928) (Brandeis, J., dissenting). Brandeis' formulation has been used as both an indictment and a justification for legally cognizable privacy interests. See R. WACKS, supra note 2, at 12 ("a sweeping phrase which is as comprehensive as it is vague"). But $c f$. PRIVACY, supra note 14, at 2 ("an excellent short definition").

17. See Roe v. Wade, 410 U.S. 179, 209-15 (1973) (Douglas, J., concurring) (right to privacy is given three formulations, all of which emphasize the individual privilege to act or to refrain from acting).

18. See R. Hixson, Privacy IN a Public Society 53 (1987); Wasserstrom, Privacy: Some Arguments and Assumptions, in Philosophical Dimensions of Privacy: AN ANTHOlogy 317 (F. Schoeman ed. 1984); see also R. WACKS, supra note 2, at 10-12 (discussing various formulatious of privacy). Gross, in defining privacy as two classes of personal tnatters, mcluding "things which tell us who a person is and what he's like," and matters pertaining to a person's hife, offers the best general definition of privacy. See Gross, supra note 2, at 172. 
of one's life. ${ }^{19}$ As these examples suggest, no single theory of privacy can capture all the nuances of the concept.

Formulating a comprehensive and exhaustive definition of privacy is beyond the scope of this Note. However, a coinmon definition of privacy provides a necessary starting point-a datuin-for any coinparison of two different legal systenıs. For the purposes of this Note, "privacy" signifies a realm of individual autonoiny in recognized and accepted social contexts. One need only assuine that the people of both the United States and Great Britain share enough of a coninon background to recognize that governinent regnlation of individual choice often adversely affects nidividual autonoiny. Privacy rights in both countries derive not only froin case law and relevant statutes, but also from the culture's institutional and philosophic foundations. Legal culture shapes each nations' determination of how nuch autonomy to grant the individual and the best means suited to that end. ${ }^{20}$ Even if we assume that each system of government reflects the sensibilities of the people it governs, the effectiveness with which systems vindicate individual liberty remains open to question.

\section{The Right of Privacy in Great Britain}

The right of privacy does not receive explicit recognition in English law. ${ }^{21}$ To the extent that privacy rights exist inıplicitly in Britain, they are formulated quite differently than in the Uinited States. Indeed, a popular treatise on privacy in Britain does not discuss freedorn of choice in the areas of sexuality, reproduction, or familial/parental relations. ${ }^{22}$ Although British law does address these issues, they do not fall within the rubric of privacy. As a result, privacy rights in Britain are a "patchwork affair."

Early judicial decisions and legislation lacked any notion of privacy. ${ }^{23}$ This reflects, in part, a reservation of authority to make laws regulating any aspect of community life. Additionally, British Govern-

19. See sources cited supra note 2 .

20. See P. ATiYah \& R. Summers, Form AND Substance in ANglo-AMERICAN Law 33-35 (1987) (attention to the context in which a legal system operates is a necessary prerequisite to understanding the system).

21. See Dworkin, Privacy and the Law, in Privacy, supra note 14, at 115.

22. See R. WACKs, supra note 2, at 1-85. This work is interesting because of what it does not address, i.e., sexuality and parenthood, as well as for what is addressed-nondisclosure of personal information to the government or others. An older work presents a "survey of the present content of civil liberties in England," but again, there is no mention of a "right of privacy" as such. H. STREET, FREEDOM, THE INDIVIDUAL AND THE LAW 9 (1963).

23. See W. Pratt, Privacy In Britain 60 (1979). 
ments resist any legal restrictions on the exercise of their powers. ${ }^{24}$ Britain has also declined to adopt domestically the right of privacy guaranteed by the European Convention on Human Rights. Although article 8 guarantees British citizens a right of privacy, Britam remains the only signatory to the European Convention on Human Rights, without a law of privacy. ${ }^{25}$ Thus, under domestic law, the imdividual citizen has no guaranteed right to seek redress against intrusive government activity.

British citizens have seized upon the concept of privacy as a potential means to obtain judicial rehef from unduly burdensome majoritarian commands. Citizens have lobbied Parhainent for the creation of a statutory right of privacy, ${ }^{26}$ argued before the domestic British courts for the enunciation of a common law right of privacy, 27 asked the British judiciary to apply article 8 of the European Convention on Human Rights and Fundamental Freedoms domestically, ${ }^{28}$ and ultimately, traveled to Strasbourg, France to obtain a hearing before an imternational human rights court. ${ }^{29}$ Unfortunately, these efforts to carve out an effective institutional process to guarantee privacy interests have largely been unsuccessful. Some external body may have to force parliamentary action. For instance, the Court of Justice of the European Community effectively could compel the British government to recognize a right of privacy. But, in the absence of external pressure, the prospects for reform are bleak.

24. The "Government" is composed of the ministers selected from the House of Commons and the House of Lords. All of its inembers have seats in Parliament. Higgins, United Kingdom, in THE EFFect of Treaties IN DOMEstic Law 123-25 (F. Jacobs \& S. Roberts eds. 1987). Critics have noted that such a system does not pronote democracy. See Mellors, Governments and the Individual-Their Secrecy and His Privacy, in PRIVACY, supra note 14, at 93. Mellors writes: "The truth is that Britain has the weakest democratic constitution of any conparable country. It is not designed to encourage a plurality of power bases within its executive. Its legislature is all but impotent. It is the anchor of an over-powerful unitary state." See Rogaly, Why Britain Should Copy Germany, Financial Times, July 13, 1990, § 1, at 16, col. 2; see also Atlas, Thatcher Puts A Lid on Censorship in Britain, N.Y. Tinies, Mar. 5, 1989, $\S 6$ (magazine) at 36, col. 1 (describing the political and social forces contributing to the debate over Charter 88, a inanifesto descrying censorship in Britain under Margaret Thatcher).

25. Scholars of the ECHR have lamented this state of affairs:

"[I]t is only in the UK, without the benefit of such incorporation by statute of the E.C.H.R. or comparable provisions in a similar constitutional Bill of Rights, that an individual who relies exclusively on such a defined right guaranteed to him by his government under the E.C.H.R. must have recourse to the Commission to vindicate it. Hence, it is not surprising to observe that the UK has the unenviable record of having had more petitions registered against it and more cases against it referred to the Court than any other member state in the Council of Europe.

Dowrick, Council of Europe: Juristic Activity 1974-86, Part II, 36 INT'L \& CoMP. L. Q. 878, 888 (1987). See J. FawcetT, Application of THE European CoNvention on Human Rights 20 (1987); Mellors, supra note 24, at 93.

26. See infra notes $30-49$ and accompanying text.

27. See infra notes $74-92$ and aeconipanying text.

28. See infra notes 121-50 and acconipanying text.

29. See infra notes 151-67 and aecompanying text. 


\section{A. Statutory Privacy Rights in Britain}

The primary source of legal rights in Britain is statutory law. "Generalized rights" are not the norm in Enghish law, ${ }^{30}$ and the courts tend to hew narrowly to establislied doctrines and to statutes adopted by Parliament. Respect for the supremacy of Parhainent, ${ }^{31}$ fear that rapid change in the law will create uncertainty, ${ }^{32}$ and a tendency to maintain a positiv. ist jurisprudential outlook ${ }^{33}$ preclude British judges froin developing social policy. ${ }^{34}$ These same factors also discourage judges from using broad, nebulous legal constructs-such as privacy-to decide cases and implement riglits.

\section{Unsuccessful Attempts to Create a Statutory Right of Privacy.} Perhaps tlie most disturbing characteristic of the British approacli to privacy is the historical lack of parlianentary and judicial interest in the protection of privacy rights. Although Parliannent historically lias approached privacy as a inatter of relations between private persons and between private persons and the press, ${ }^{35}$ in recent years, back bench

30. See P. ATIYAH \& R. SUMMERS, supra note 20, at 266; Younger REPORT, supra note 15, at 28. By "generalized rights" I mean rights that lack specific definition (privacy, freedom of speech, due process of law, etc.) and rights that are not limited by a specific text.

31. See P. Atiyah \& R. Summers, supra note 20, at 42-53. Atiyah and Summer's book provides a theoretical and practical discussion of the systemic differences between the U.S. and British legal systems.

32. See id. at $142-43$.

33. Id. at 421.

34. Street writes that:

[T] he British judge has trained limiself as an umpire, avoiding clashes with the Government of the day, cutting himself off from politics whenever possible, and divesting his judgments of social, economic, and political references to the utmost. This outlook has made him unable to provide the kind of interpretation necessary for the written constitutions of other parts of the Commonwealth ....

H. STREET, supra note 22, at 286; see also YOUNGER REPORT, supra note 15, at 211.

35. See W. PRATT, supra note 23, at 128. Although individuals in Britain have viewed privacy as encompassimg more than protection from private parties, most of the early legislative reform efforts focused only on this aspect. In the tort context, Parliament made three unsuccessful attempts in the 1960 s to legislate an action for invasion of privacy against non-governmental actors. Lord Mancroft introduced a Privacy Bill on February 14, 1961 that provided for a right of action against the press for stories published about individuals without their consent. R. WACKs, supra note 2, at 5-9. The Act was intended to discourage the public disclosure of private facts. See 229 PARL. DEB., H.L. (5th ser.) 607-617 (1961).

Parliament has expressed concern for protecting freedom of the press over the individual's privacy interest. However, the extent of this concern is limited. The Official Secrets Act has been invoked regularly against the British press in favor of the government's privacy interest. See $\mathbf{R}$. WACKS, supra note 2, at 16-17. Iromically, a free press trumps an individual's privacy interest, but not the government's privacy interest. For a British recognition of the general problem, see YOUNGER REPORT, supra note 15, at 195-200.

In 1967 and 1969, bills that created a general privacy right against other private interests as well as against the press were introduced. In 1967, the Lyon's Bill sought to define privacy as the right to be let alone, stating that privacy was "the right of any person to preserve the seclusion of himself, his 
members of Parliament liave introduced several bills that would recognize a more generalized notion of privacy. ${ }^{36}$

In response to parliamentary support for a privacy act in the late 1960s, Parliament created the Committee on Privacy, chaired by Kenneth Younger. ${ }^{37}$ The Younger Committee's mandate extended only to private and quasi-private interference with individual privacy; specifically, it did not extend to governmental intrusions. ${ }^{38}$ Nevertheless, the committee's survey on the public's perception of privacy concluded that:

In identifying privacy with the state of being let alone to do as one wished, most respondents appear[ed] to have been thinking primarily of the dangers of interference with their liberty by a possible totalitarian governinent, an aspect [of privacy] which hies outside our terms of reference, and only secondarily of preserving their privacy as a valued element in the quality of life froin interference by non-governmental bodies and their fellow citizens. ${ }^{39}$

The Younger Committee reviewed the subject for three years before concluding that Britain needed neither a general right of privacy nor a specific tort action for the invasion of privacy. ${ }^{40}$ The Committee found that a general right of privacy against governmental and private interests was incompatible with the concept of society. ${ }^{41}$ The "riglit to be let alone" was viewed as unreasonable in a commumity dedicated to coinmon goals and purposes. ${ }^{42}$ The Younger Committee's conclusions dovetail with the ambivalence of soine British commentators to an Americanstyle right of privacy - both groups found that the benefits conferred by a privacy construct are dubious at best. 43

family, or his property, from any person." W. PRATr, supra note 23, at 161. Lyon's bill did not focus on the press, nor did it target governmental invasions of privacy. Instead, Lyon wanted to extend the individual's privacy interest to reach material gathered by other private individuals or groups via new technologies. Id. at 162. No action was taken on Lyon's bill. In 1968 and 1969, a unovement to establish an English Bill of Rights with a privacy clause was defeated. Concerns over the creation of an ill-defined cause of action and over the possible limitations on frecdom of the press prevented passage. Id. at 169. A third bill, the Walden Bill of 1969 , would have created a privacy tort through the use of a general definition of privacy that enumerated infringements, defenses, and examples. See W. PRATT, supra note 23, at 180 . Although the Walden Bill did not draw tremendous support, it did induce the Government to create a committee on privacy.

36. See infra notes $44-49$ and accompanying text.

37. See W. PRATT, supra note 23, at 183-84.

38. YouNGER REPORT, supra note 15, at 2-3.

39. Id.

40. Id. at 200-05.

41. See Mellors, supra note 24 , at 90 .

42. YOUNGER REPORT, supra note 15 , at 10 .

43. R. WACKs, supra note 2, at 21-23. The British view American privacy law with inuch skepticism. Consider the Younger Committee's appraisal of the then new decisions in the Griswold line:

The decisions, backed by some statements in the Constitution, justify the conclusion that privacy itself is widely recognized as a legally defensible riglt in the United States, but not 
The Younger Committee hearings and report stimulated much debate, but no legislative action. ${ }^{44}$ Despite this setback, the privacy debate continued in Britain. In the 1988-89 session of Parhament, M.P.s John Browne and Tony Worthington introduced bills to guarantee a right of privacy and a right of reply, both to run only against the press. ${ }^{45}$ In response, the Government constituted a second committee on privacy ${ }^{46}$ The Committee on Privacy and Related Matters (the Calcutt Comınittee) issued its final report in June 1990. But once again the privacy committee's terms of reference limited its investigations to non-governınental intrusions of privacy. ${ }^{47}$

The Calcutt Committee concluded that tort law did not need a right of privacy cause of action. ${ }^{48}$ The difficulty in defining privacy did not lead to the rejection of the tort. Rather, the uncertainty with regard to the effect of such a tort on the ability of the press to function produced the committee's rejection. ${ }^{49}$

The current Government does not appear ready to address the fundamental problem with British law: the lack of a right of privacy that can be asserted against the state. The Calcutt Committee Report merely

that it is established as a coherent principle of law or that is has significantly contributed to respect for privacy in every-day life, especially by the mass publicity media.

YOUNGER REPORT, supra note 15, at 30. Coherence in a principle of law is certainly desirable; nevertheless some interests may not fit neatly with other interests or lend themselves to easy application in specific cases. See Rogaly, supra note 24.

44. W. PRATT, supra note 23, at 203.

45. See Report of the Committee on Privacy and Related Matters, CMNd. No. 1102, at 1 (1990) (Chairman: David Calcutt, Q.C.) [hereinafter Calcutt Committee Report].

The Committee also was organized in response to perceived abuses by the popular pressspecifically, an incident in which reporters from the Sunday Sport barged into a popular actor's hospital room in order to report on his condition. See Snoddy, The Press on A Slippery Slope, Financial Times, June 23, 1990, $\S 1$ at col. 1. The case of Gordon Kaye, the actor, prompted the committee to recommend a new criminal law. Id.

46. Calcutt Committee Report, supra note 45 , at 1.

47. The Calcutt Committee Report noted:

A number of those who submitted evidence to us argued that our terins of reference were too narrowly drawn; some urged us to extend our inquiries to include official secrets, data protection, coinputer hacking, and telephone tapping. While we recognize that all these issues may be relevant to individual privacy, they do not generally concern intrusion by the press.

Id. at 4.

48. Id. at 46 .

49. The supreme irony of the Calcutt Committee Report occurred when the Committee referenced articles of the ECHR and suggested that the individual's interest in privacy should be bal. anced against the community's interest in a free press. Id. at 7-8, 13. The irony is that the ECHR applies first and foremost against government action. Thus, the Calcutt Committee used a prohibition on government interference to attempt to justify restrictions on a private actor-the press. See infra note 99 and accompanying text. Although private activity may trigger provisions of the ECHR, the primary focus of the ECHR's restrictions is on government infringements of basic civil liberties. See P. van Dijk \& G. Van Hoof, Theory and Practice of the European ConvenTION ON HUMAN RIGHTS 13-18, 310 (1984). 
provides additional evidence and an interesting example of this shortcoming.

2. Explicit Recognition and Rejection of Privacy Rights by Parliament. Despite the lack of a written constitution and the failure of Parliament to enact privacy legislation, British citizens are not entirely without remedies for mvasions of privacy. In many respects, a different approacl rather than any difference in substance separates Britain and the United States with regard to privacy rights. Although Parliament has never enacted a Privacy Act, it mdirectly lias created distinct privacy rights in a number of areas. In some cases, these parhamentary laws grant broader coverage for individual freedoin of action than the American "right of privacy."

Britain's approach demonstrates that a majoritarian body sonietimes can adequately resolve the tension between individual hiberty and comnuumity. ${ }^{50}$ In contexts in which a inajoritarian consensus exists, Parliainent has granted autonoinous decisionmaking to the individual. Sodoniy, prostitution, abortion, and data protection provide several examples. 51

a. Statutory recognition of autonomy interests. Parliament has recognized several autonomy interests by statute. First, in contrast to niany states in the United States, the British Sexual Offences Act allows homosexual sodomy in the honie provided that the act is not engaged in for nionetary gain. ${ }^{52}$ The British approach to the problem of prostitution

50. Britain's approach is in keeping with the contentions of some current U.S. Supreme Court Justices' that the tension between individual liberty and community inoral values is best resolved by inajoritarian legislative bodies. See Michael H. v. Gerald D., 491 U.S. 110, 127-30 (1989). Justice Scalia takes the position that tradition, usually enunciated best by the legislatures, should guide the delimitation of privacy interests. But although legislatures are accountable to some extent, they often are unwilling to tackle issues because of a fear of adverse reaction by a vocal plurality of the voters.

51. See infra notes 52,55-61 and accompanying text; see also P. ATIYAH \& R. SUMMERS, supra note 20, at 299-306. The party system in Great Britain makes it possible for a Member of Parliament (MP) to vote for a bill that is repugnant to his constituency and remain in office. Id. at 302-03. If the party decides to take an unpopular stand, then the party itself eventually will be held accountable, but individual members will not immediately feel the wrath of the public. Id. at 303 .

Public sanction of individual parliamentary acts is, at least in some cases, only indirect, if it exists at all. Thus, even though the election of Parliament is an expression of majoritarian desires, the acts of the body do not necessarily always coincide with public opinion. Conversation witll P.S. Atiyal1, in Durham, Nortlı Carolina (Marcl1 22, 1989).

52. Sexual Offences Act, 1967, ch. $60 \S 1$. Conversely, the Supreme Court of the United States refused to grant the act of sodomy constitutional protection. Bowers v. Hardwick, 478 U.S. 186 (1986). Although Britain legalized consensual homosexual conduct, the Britisl approach is not terribly deferential to the individual imterests when determining wliether or not to occupy a given field legislatively. See infra notes 265-73. 
provides a second illustration. Rather than crimmalize payment for sexual favors, the British regulate only public solicitation and pimping. 53 Prostitution itself is not illegal; Britain has recognized that it is unrealistic, and perhaps unsafe, to maintain a prudish attitude in light of society's long practice. Abortion, however, provides the best example of an area in which Parhainent has acted to secure an autonomy interest cominonly associated with the right of privacy.

Theoretically, the right to abortion enjoys less protection in Britain than in the United States. Whereas in the United States a "right of privacy" protects a woman's "fundainental liberty" to decide whether or not to abort her fetus, ${ }^{54}$ the British Abortion Act generally criminalizes abortion in Britain. In practice, however, the Act's exception clause swallows the whole by allowing legal abortions for the physical and mental well-being of the mother or of existing children and for deformed fetuses. ${ }^{55}$ By hiberally construing this provision, the courts, with ParliaInent's tacit approval, effectively have created abortion on demand. ${ }^{56}$

Pro-life advocates in Britain have challenged this interpretation of the Act. In Royal College of Nursing of the United Kingdom v. Department of Health and Social Security, ${ }^{57}$ the House of Lords rejected a petition by pro-life nurses arguing that a hteral reading of the statute's requireinent for "termina[tion] by a registered medical practitioner"58 required doctors to personally administer a drug resulting in miscarriage in eighteen to twenty hours. ${ }^{59}$ Royal College is just one example of unsuccessful efforts to restrict de facto abortion on demand. The de facto statutory right to an abortion also has been protected against challenges based on the Infant Life Protection Act, and agamst challenges by fathers and other outsiders. ${ }^{60}$ The inessage to be gleaned front these cases is that only the state has standing to enjoin an abortion operation. ${ }^{61}$

53. Street Offenses Act 1959, 7 \& 8 Eliz., ch. $57, \S \S 1-4$. One of the ironies of this policy is that men cannot be punished for paying for sex, while women can still go to jail for solicitation.

54. Roe v. Wade, 410 U.S. 113 (1973); see infra notes 194-205 and accompanying text.

55. Abortion Act, 1967, ch. 87, § 1 .

56. See Ryan, Rights That Go Awry, London Times, Aug. 23, 1990, at 8, col. 2 (David Steel's Abortion Act "was a classic piece of compromise legislation. It declared abortion criminal except in some situations." The result allows abortions in the same circumstances which the U.S. Supreme Court granted women a constitutional right to an abortion in Roe v. Wade, 410 U.S. 113 (1973).

57. 1981 App. Cas. 800 (H.L.).

58. Abortion Act, 1967, ch. 87, § 1; see 1981 App. Cas. 800, 828 (H.L.) (discussing the statutory language).

59. Lord Denning on the Court of Appeal had rigidly applied the provision as the nurses requested, commenting that he doubted Parliament would amend the law so as to allow de minimis supervision. Id. at $806-07$ (C.A.).

60. Grubb \& Pearl, Protecting the Life of the Unborn Child, 103 L.Q. REv. 340, 340 (1987).

61. Id. at 342 . 
The British government's position seems to be that abortion does not implicate a sufficient governmental concern to justify a government proscription against it. However, Parliament's deference to a woman's decision whether to have an abortion has not led to general discussions of rights of privacy. Rather, British citizens appear to rely on a principle of governmental self-restraint coupled with a notion of liberty vesting im the citizenry - that which Parhament does not prohibit is permitted. ${ }^{62}$ Thus, privacy is "protected" via indifference or deliberate inaction. However, no procedure exists to prevent Parhament from legislating in areas that impinge on privacy: Individual autonomy is subject to summary abrogation by parhamentary fiat.

A final example of the protection of limited privacy interests by statute is the Data Protection Act of 1984, which regulates the collection and dissemination of computer data. ${ }^{63}$ The Act guarantees an individual the right to access a computer database that contains information about him.64 Parhainent accomplished this goal by requiring firms collecting personal information on computer databases to comply with registration and reporting requirements. The Act, although coinprehensive within its area of apphication, contains an exception for the government when "national security" is implicated. ${ }^{65}$ Similar to acts passed by the United States Congress in the late 1960s and early 1970s, ${ }^{66}$ the Data Protection Act protects personal information-furthering privacy-but it does not directly relate to individual autonomy. The Data Protection Act, the Abortion Act, and the Sexual Offences Act are examples of Parliament's willingness to protect privacy in certain cases.

b. Parliament sometimes fails to protect some privacy interests where the powers of government are directly in question. When the governinent wishes to restrict an individual's freedon1, or to shield itself from public scrutiny, British law grants individual citizens little recourse. Although Parliament has been quite permissive on privacy issues relating to abortion, homosexuality, and prostitution, it has been somewhat neanderthal in the areas of official government secrets and search and seizure law. The following examples illustrate this problem.

With regard to searclı and seizure, the Police and Criminal Evidence Act grants broad power to arresting officers to search louses without a

\footnotetext{
62. H. STREET, supra note 22, at 10,284 .

63. Data Protection Act, 1984, ch. 35, §§ 1-3.

64. Id. § 21(1).

65. Id. $\S 27(1)$.

66. See infra notes 177-78 and accompanying text.
} 
warrant. 67 Although section four of this Act limits searches to the subject matter of the entry, this is of little consolation to one wliose bedroom is ransacked. ${ }^{68}$ Thus, privacy in the home is tenuous under the present state of the law-and is always subject to complete revocation by Parliament. 69

Even when Parliament acts to protect privacy, parliamentary reforms are often minimal. In 1985, responding to Malone v. Metropolitan Police Commissioner, ${ }^{70}$ Parliament adopted the Interception of Commumications Act, ${ }^{71}$ which protected some privacy interests through procedural reforms. Prior to the 1985 Act, judicial review of government

67. Police and Criminal Evidence Act, 1984, ch. $60, \S 17$. In contrast, in the United States a general search may not be conducted absent a warrant describing the items to be taken. Even in the Umited States there are exceptions--such as the "plain sight" rule-to the prohibition against general searches. See Coohidge v. New Hampshire, 403 U.S. 443, 465-67 (1971) (items in plain view may justify taking relevant evidence not listed in a warrant, but doctrine may not be used to justify a general "exploratory" search with or without a warrant); M. ABERNATHY, CiviL LIBERTIES UNDER THE CONSTTTUTION 83-109 (5th ed. 1989); MCCORMICK ON EVIDENCE $§ 169$, at 479-81 (E. Cleary 3d. ed. 1984).

68. However, local police are not immune from tort law, unless Parliament specifically vitiates such habihty. See Morris v. Beardmore, 1981 App. Cas. 446 (H.L.) (constable who entered home during unlawful search in drunk driving mvestigation civilly liable for trespass); H. STREET, supra note 22, at 12-32. Similarly, in the Umited States, local police officers are held accountable for their actions under 42 U.S.C. $\S 1983$ (1988) and federal officers through the Bivens doctrine. For a discussion of section 1983, see Monroe v. Pape, 365 U.S. 167, 184 (1961). For the extension of constitutional torts to searches by federal agents, see Bivens v. Six Federal Unknown Agents, 403 U.S. 388 (1971). The principle difference between the United States and Britain on inposing liabilities on law enforceinent personnel is that Parhament may vitiate liability at will, whereas the Congress would presumably be himited by the federal Constitution-Congress could not authorize unconstitutional conduct by state or federal agents.

69. See infra notes $80-83$ and accompanying text.

70. [1979] 1 Ch. 344 (Ch.). Malone itself concerned the police practice of wiretapping and "metering" without any independent judicial or administrative supervision. Id. at 368. "Metering" is the recording of incommg and outgoing phone numbers, and not an actual recording of the conversations. Under the then-existing legislation, the local constables were free to monitor or meter phones with a minister's approval. Id. The legislation did not provide for any judicial oversight. Id. at 368-69. See 1 V. Berger, Case LAW of THE European Court of Human Rights: 19601987 at 255-60 (1989) (procedural history of the Malone case). Great Britain did not reform its domestic surveitlance laws until called to task by the ECHR (sometimes referred to as the Strasbourg court). V. BERGER, supra, at 257, 260. The European Commission of Human Rights declared Malone's application to the European Court of Human Rights (hereinafter European Court) admissible in 1981, Malone v. United Kingdom, [1982] 4 Eur. Hum. Rts. Rep. 330, 349 (1981), and the European Court of Human Rights heard and decided the case. Malone v. United Kingdom, [1985] 7 Eur. Hum. Rghts. Rep. 14 (1984); V. BERGER, supra, at 258-60. The European Court found that Britain's failure to regulate government interception of private communications violated article 8. Malone, 7 Eur. Hum. Rts. Rep. at 41-47. Ultimately, a friendly settlement was reached between the parties; Britain passed the Interception of Communications Act, 1985, ch. 56 and paid $£$ 18,000 for his legal costs and damages. V. BERGER, supra, at 260. The Malone case is an cxample of the good that can result when individuals pursue their claims in the European Court of Human Rights. See infra notes 151-67 and accompanying text.

71. Interception of Cominunications Act of 1985, ch. 56. 
wiretaps was not required before the government could monitor private conversations. The 1985 Act, however, did not create or recognize a right of privacy in the citizenry. Rather, the Act redrew the rules relating to the interception of private communications by government officials. The Act required judicial supervision of wiretaps and delimited the circuinstances in which such a warrant could be issued. ${ }^{\mathbf{7 2}}$

The Interception of Commuincations Act vindicates the individual's privacy interest only in the most limited contexts. The Act shows that Parhament can protect privacy in limited contexts agamst arbitrary government action when required to do so. ${ }^{73}$ It also illustrates that privacy, as a general matter, will remain largely unprotected.

\section{B. The Role of the British Judiciary in Securing Privacy Rights}

In contrast to Uinited States courts, the British courts consistently refuse to recognize or create a right of privacy in any context. British judges believe it is "no function of the courts to legislate in a new field."74

72. Government agents are immune from liability, provided that they were acting in a matter authorized pursuant to section two of the Act, which provides that:

(2) The Secretary of State shall not issue a warrant under this section unless he considers

that the warrant is necessary-

(a) in the interests of national security;

(b) for the purpose of preventing or detecting serious crime; or

(c) for the purpose of safeguarding the economic well-being of the United Kingdom.

Additionally, a Commissioner provides governmental oversight and has the duty to inform the Prime Minister of any suspect interceptions by the government. Finally, the courts are charged with ensuring compliance with the Act. Interception of Communications Act, 1985, ch. 56, $\$ 8$. The provisions of the Act protecting citizens from government surveillance of their correspondence are entirely consistent with Klass v. Federal Republic of Germany, [1979-80] 2 Eur. Hum Rts. Rep. 214 (1978), in which the European Court allowed West Germany to intercept communications under a stringent administrative scheme, even thought the scheme did not involve direct judicial review.

73. Parliament did not pass the Act spontaneously. Rather, an external body precipitated reform of government surveillance of the citizenry. In Malone, the European Court of Human Rights (European Court) found that the government of Great Britain violated the right of privacy guaranteed by article 8 of the European Convention on Human Rights. Thus, the Interception of Communications Aet, unsurprisingly, tracks the permissible exceptions to the right of privacy provided in article $8(2)$. ECHR, supra note 10 , art. $8(2)$, at 230 . The allowable exceptions relate to "national security, public safety or the economic well-being of the country, for the prevention of disorder or crime, for the protection of health or morals, or for the protection of the rights and freedoms of others." The general notes to section 2 of the Interception of Communications Act note that the wording of the section "also reflect the wording of Article eight of the European Convention for the Protection of Human Rights and Fundamental Freedoms." Explanatory notes, Interception of Communications Act, 1985, ch. 56, in 45 Halsbury's StatuTes of ENGlaNd aNd Wales 419 (4th ed. 1988).

74. Malone, [1979] $1 \mathrm{Ch}$. at 372. However, there is popular sentiment for the creation of such a right by the domestic British courts. See, e.g., Justinian, Establishing the Right to Be Left Alone, Financial Times, Mar. 26, 1990, $\S 1$, at 40, col. 2 ("[T]lere is a strong argument for letting the law grow out of a series of rulings in individual cases. The judges' riposte to the suggestion that they should construct a law of privacy is that it is too late in the day for the courts to create new remedies."). 
Because the British courts see legal reform as the prerogative of Parliament, it would be anomalous for them to unilaterally create a right of privacy.

\section{The British Judiciary Will Not Recognize A Right of Privacy in} the Common Law. British citizens, in light of Parliament's inaction, liave attempted to circumvent the legislature by petitioning the British courts to create a common law right of privacy. Without fail, the courts have refused to do so. One route souglit to secure a common law right of privacy was through the extension of the torts of breacli of confidence and trespass. For instance, in Director of Public Prosecutions v. Withers, Lord Simon ${ }^{75}$ declined to recognize the tort of invasion of privacy. ${ }^{76}$ Althougl he adimitted that the tort arguably could be derived from the tort of breach of confidence, the Lord believed that court action would be imappropriate because Parliament was studying the issue. Ultinately, Parliament took no action, and in the late 1970s the issue of a common law right of privacy remamed before the courts.

Article 8 of the ECHR presented a second route to a common law right of privacy througli judicial action. However, the courts rejected article 8 as a source for estabhishing a common law riglit of privacy. The Malone case ${ }^{77}$ effectively foreclosed the development of a common law riglit of privacy in domestic Britisl law. Malone expressed the judiciary's determination to avoid the creation of a general right of privacy:

No new right in the law, fully-fledged with all the appropriate safeguards, can spring froin the head of a judge deciding a particular case: only Parliament can create such a right. ... One of the factors that must be relevant in such a case is the degree of particularity in the right that is claimed. The wider and more indefinite the right claimed, the greater the undesirability of holding that such a right exists. ${ }^{78}$

Althougli much Englisli case law, as well as provisions of the European Convention on Human Rights and the U.N. Declaration of Human Riglits, was argued in support of a common law right of privacy, Sir Megarry concluded, "I can find nothing in the authorities or contentions

75. A "law lord" is a member of the House of Lords who is appointed for life (he or she is not a member of the peerage) and who sits in decision over the appeals taken from the lower British judiciary. The House of Lords, as a whole, does not sit and decide cases. Rather, the small cadre of law lords discharge this function. See P. ATIYAH \& R. SUMmERS, supra note 20, at 269.

76. 1975 App. Cas. 842, 862-63 (H.L.). See also Berstein of Leigh (Baron) v. Skyviews \& General Ltd., [1978] 1 Q.B. 479, 488 (Q.B.) (no remedy for breach of privacy unless plaintiff can establish the elements of an already recognized tort).

77. [1979] $1 \mathrm{Ch}$. 344. The Chancery Division upheld police attempts to gather evidence for a possible proseeution against Malone. Because British domestic law did not recognize any privacy right, Malone did not appeal the privacy issues to either the Court of Appeal or the House of Lords. Malone v. United Kingdom, [1982] 4 Eur. Hum. Rts. Rep. 330, 337-38 (1981).

78. Malone, [1979] $1 \mathrm{Ch}$. at 372-73. 
that have been put before me to support the plaintiff's claim based on the right of privacy."79

One last example illustrates that the British courts will defer to Parhamentary commands, no matter how invasive to imdividual privacy. Regina v. Inland Revenue Commission, ex parte Rossminster provides an exainple of this phenomenon. ${ }^{80}$ Rossminster involved government searches to enforce criminal tax fraud and answered the basic question of how far the government could go to collect its revenues. ${ }^{81}$ According to the House of Lords, the government could go quite far indeed: The Lords found that the government may search hoines and businesses with very general warrants. ${ }^{82}$ The House of Lords simply gave effect to a broadly crafted law duly adopted by Parhament. Because the law did not require that a warrant issued under the act specify the authority under which it was issued or the items which could be seized, no such requirements would be imphied by the House of Lords. Thus, as long as the government's activity is expressly authorized by Parhament, no claim of privacy under the common law (guaranteed primarily by the tort of trespass) may stand in the way of state action based on the authorization. ${ }^{83}$

2. The Recognition of the Notion of Privacy by the British Courts Via Statutory Interpretation. Although the judiciary refused to recognize a general right of privacy absent legislative authority, it will not

79. Id. at 375. With respect to article 8 in particular, the court observed that the domestic courts of England do not have jurisdiction to adjudicate the claims that arise under the ECHR and that the ECHR is not part of the domestic law of Britain. See infra notes 121-36 and accompanying text.

80. 1980 App. Cas. 952 (C.A.).

81. Id. at 969-71. Petitioners premises were searched by tax agents under a general warrant that did not specify any offense. Id. at 1015-16. On July 12, 1979, four warrants were issued under section $20 \mathrm{C}$ of the Taxes Management Act, 1970, ch. 9, as substituted by the Finance Act, 1976, ch. 40 , sched. 6 , for the search of two private homes and two businesses. Id. at 997, 1001. The warrant, consistent with section $20 \mathrm{C}$, authorized the police to search the named premises and "seize and remove any things whatsoever found there which you have reasonable cause to believe may be required as evidence for the purposes of proceedings in respect of [a criminal revenue offence]." Id. at 1003. Lord Salmon would have upheld the result reached in the Court of Appeal, but on much narrower grounds than Lord Denming advocated. Id. at 1017-18.

82. The Act did not require the warrant to specifically state the iems to be taken-it authorized a general search. Rossminster, 1980 App. Cas. at 1003-04. Further, section 20C(3) authorized the general seizure of any evidence the executing officer believed might be helpful to the government's case. Id. at 1005.

83. Despite the contemporary British courts unsympathetic view toward the creation of a general privacy right, individual judges have becn quite impressed with the arguments advanced in favor of such a right. In particular, Lord Denning, Master of the Rolls, was quite ready to recognize a privacy right in Rossminster. He wrote: "A good end does not justify a bad means. The means must not be such as to offend against the personal freedom, the privacy and the elemental rights of property." Id. at 976 . 
protect government officials froin liability for illegal conduct in the absence of express parliamentary approval. The British judiciary applies a notion of privacy as a general principle of statutory construction. ${ }^{84}$ Principles of statutory construction can provide some inodicum of protection for privacy interests.

Morris v. Beardmore provides an example of British courts applying this notion of privacy. ${ }^{85}$ In Morris, a gentlennan involved in an accident left the scene of the incident and returned loone. Over two hours later, local police arrived at his home and asked to speak with him. When Mr. Morris refused, the police broke into his house and dennanded that he submit to a breathalyzer test (that he failed). The House of Lords decided the question as whether the police conduct was justified under a general statute for the enforcennent of drunk driving laws. ${ }^{86}$ The Lords decided in favor of Morris based on a principle of statutory construction: Parhament is required to expressly authorize official tortious conduct in order to preempt otlerwise applicable common law liability for government officials. ${ }^{87}$

In this case, Lord Edınund-Davies nearly articulated a general notion, although not a "right," of privacy: "[T]o reject the appeal would entitle a constable who, in deliberate violation of the householder's riglits, forcibly invades his privacy [to conduct a search]. . . . I cannot accept that Parliament conteinplated anything of this sort." 88 Lord Edmund-Davies recognized that parliainentary inaction, by itself, does not justify undue interference with privacy interests that otherwise are protected (albeit indirectly) through tort law.

Other opimions in Morris were equally solicitous toward a notion of privacy. For instance, the speech of Lord Scarnan in Morris is intriguing for its similarities to American judicial privacy law: 89

84. Malone v. Metropolitan Police Comm'r, [1979] 1 Cl. 344, 380-81 (Cli.) (Sir Megarry, in dicta, says that he personally would welcome parliamentary reform, but that it is not the court's prerogative to create a new right). The Vice Chancellor's approach is consistent with the general deference given to Parliament by the Courts. See P. ATIYAH \& R. SummerS, supra note 20, at 22729.

85. 1981 App. Cas. 446 (H.L.).

86. Id. at $453-54$.

87. Id. at 456. "The presumption is that in the absence of express provision to the contrary Parliament did not intend to authorize tortious conduct; and this presumption, in my view, owes nothing to the European Convention on Human Riglits ...." Id. (Lord Diplock). The Lords did not want to rest their holding on the ECHR, because to do so would make the ECHR operational at the domestic level. See infra notes 121-50 and accompanying text.

88. Id. at 461-62 (Lord Edmund-Davies).

89. See, e.g., Moore v. City of East Cleveland, 431 U.S. 502 (1976) (discussing the risks involved in protecting substantive liberties not specifically in the Bill of Rights). 
I have dehberately used an adjective with which has an unfamiliar ring to the ears of common law lawyers. I have described the right of privacy as "fundamental." I do so for two reasons. First, it is apt to describe the importance attached by the common law to the privacy of the home. ... Secondly, the right enjoys the protection of the European Convention For the Protection of Human Rights and Fundamental Freedoms ... which the United Kingdom ratified . . . 90

Yet Lord Scarman spoke only in the context of a case in which Parliament's intent was ambiguous. If Parliament had expressly authorized the objectionable police conduct, then the reliance on private tort law to protect Morris' privacy would be unavailing. ${ }^{91}$ Such references to privacy as a "fundamental right" indicate a sympathy among the British judiciary for privacy concerns. Nevertlieless, tlie judiciary remains unwilling to undertake unilateral action to protect privacy.92 The ultimate result, to American eyes, is unsatisfactory. British courts lament that privacy concerns are legitimate, but only apply the notion of privacy at the margins (if at all).

The courts vindicate privacy interests only when Parhament has affirmatively endorsed the imterest or has left some ambiguity in an authorization of intrusive conduct. If privacy concerns are legitimate, then the courts should have a greater role in securing them. The common law is not static; if the courts can create an action for trespass, they could also create a right to be let alone.

\section{The European Convention on Human Rights and Fundamental Freedoms As a Source of a Right of Privacy}

The failure of British domestic law to recoginize a riglit of privacy does not foreclose its existence altogether. The European Convention on Human Rights guarantees a right of privacy to individual citizens against the governments of siguatory states, which include Britain. ${ }^{93}$ Because Parliament has refused to give the ECHR domestic effect, British courts do not vindicate the individual autonomy rights recognized under the ECHR.94

90. Id. at 464 .

91. See infra notes 121-67 and accompanying text.

92. See P. ATtYAH \& R. SUMmers, supra note 20, at 228-29, 238, 269.

93. Article 25 of the ECHR limits the jurisdiction of the European Commission to the individual complaiuts of those seeking to vindicate rights guaranteed by the ECHR brought against states that recognize the authority of the Commission. P. VAN DIJK \& G. VAN HOOF, supra note 49, at $69-$ 71. Article 46(1) requires the consent of states to the jurisdiction of the European Court. Presumably, signatories must accede to both in order to be subject to inandatory commands from the institutions of the ECHR. ECHR, supra note 10, at 246. However, article 24 allows for the Commission to hear complaints brought by other signatory states without an article 25 declaration. Id. at 236 .

94. The British record before the European Court is abysmal. From 1983 to 1985,392 complaints were filed with the Commission against the U.K. compared to France with 174, the Federal 
1. Practice and Procedure Under the European Convention on Human Rights and Fundamental Freedoms. Following the end of World War II, the nations of Western Europe wanted to create an international frainework to safeguard certain basic human freedoms against government infringement. ${ }^{95}$ Acting under the auspices of the Council of Europe, a convention was drafted in 1950 and the European Convention On Human Rights and Fundamental Freedoms (ECHR) becaine effective on September 3, 1953.96 Today, the Council of Europe consists of the twenty-one post World War II democracies of Western Europe. ${ }^{97}$

The ECHR creates two bodies independent of the regular agencies of the Council of Europe: the European Commission on Human Rights $^{98}$ and the European Court of Human Rights. ${ }^{99}$ Together with the

Republic of Germany with 312, and Italy with 91 . Dowrick, supra note 25 , at 888 n.48. Since 1959, when the European Court began hearing cases, 27 U.K. cases have been referred by the Commission. Id. at $888 \mathrm{n}$.49. The numbers for other signatories with Britain's population were France (1), Federal Republic of Germany (16), and Italy (12). Britain's record of adverse judgements is also particularly poor. Id. See Higgins, United Kingdom, in THE EFFECT OF TREATIES IN DOMESTIC LAW 123, 130 (F. Jacobs \& S. Roberts eds. 1987).

Britain's ability to fulfill its international obligations as a signatory to the ECHR are seriously tested by the absence of a legally cognizable privacy right. See infra note 123; Ryan, supra note 56, at 8, col. 1 (British record before the European Court is poor). The Liberal Dernocratic Party recently has proposed incorporating the ECHR into British domestic law and establishing a United Kingdon Commission on Human Rights. See Hibbs, First Written Constitution Proposed, DalLY TelEgRAPH, July 6, 1990, $\S 1$, at 12, col. 1 .

95. P. VAN DUK \& G. VAN HOOF, supra note 49 , at $1-2$.

96. Id.

97. The following states are inembers of the Council of Europe: Austria, Belgium, Cyprus, Denmark, the Federal Republic of Germany, France, Greece, Iceland, Ireland, Italy, Liechtenstein, Luxernbourg, Maita, the Netherlands, Norway, Portugal, Spain, Sweden, Switzerland, Turkey, and the United Kingdom. Id. In 1990, Hungary becane the first of the newly liberated East Bloc nations to join the Council of Europe. N.Y. Times, Nov. 6, 1990, $\S$ A, at 15, col. 1 .

Distinct froin the European Economic Comnunity (EEC), which has only 12 nembers, the Council of Europe is not a supranational organization, but rather is an intergovernmental entity. The basic distinction is that the ECHR establishes an international organization, not a quasi-sovereign body. The EEC nay directly displace domestic laws that conflict with policies of the EEC. See e.g., $R e$ Detergents Directive: E. C. Commission v. Italy, 1980 E. Comm. Ct. J. Rep. 1099, 1104-06, [1981] 1 Common Mkt. L. R. 331, 342-43 (Ct. J.) (Italy violated article 169 of the Treaty of Rome by failing to bring its domestic law in line with Council Directive 73/404). The ECHR, on the other hand, does not vest the enforceinent agencies with any power to act directly on the member states. See Bartsch, The Implementation of Treaties Concluded with Council of Europe, in THE EFFECT OP TREATIES IN Domestic LAw 197, 199 (F. Jacobs \& S. Roberts eds. 1987). Thus, the Council of Europe lacks plenary power to alter the donestic laws of the inember states.

98. The European Commission of Hunian Rights examines coinplaints that are filed in a timely fashion. ECHR, supra note 10, art. 19, at 235; P. VAN DIJK \& G. VAN Hoof, supra note 49, at 1823. The Commission receives complaints, determmes their sufficiency, and attenipts to negotiate a "friendly settlement." P. VAN DUK \& G. vaN HOOF, supra note 49, at 91-92. For the requirements of a valid petition, see articles 26-28 of the ECHR supra note 10, at 238-40. See also, J. FAwCETr, supra note 25, at 355-75; P. VAN DIJK \& G. VAN HoOF, supra note 49, at 53-91; Boyle, Practice and Procedure on Individual Applications under the European Convention on Human Rights, in GUiDE to International Human Rights Practice 136-47 (H. Hannun ed. 1984). 
Council of Ministers, ${ }^{100}$ these bodies handle the day-to-day administration of the ECHR.

The ECHR, unlike many human rights conventions, effectively secures the rights guaranteed under its provisions. ${ }^{101}$ Although the European Court cannot force member states to comply with its decisions, compliance with its judgments is the norm. ${ }^{102}$

Article 1 of the ECHR requires that signatories' domestic laws be consistent with the substantive guarantees of the ECHR. ${ }^{103}$ Signatories can comply with article 1 either by mcorporating the treaty directly into their domestic laws or by recognizimg parallel rights under domestic law. ${ }^{104}$ In fact, all but six signatories ${ }^{105}$ give domestic effect to the treaty

99. Articles 48 and 49 of the ECHR set out the jurisdiction of the European Court. ECHR, supra note 10, at 246-48. Under article 47, the Court may take a case only after the Commission has failed to reach a friendly settlement. Id. at 246 . A dispute may be referred to the Court by 1) the Commission, 2) a contracting state whose national is the alleged victim, 3) a contracting state who referred the case to the Commission imitially, or 4) the contracting state against whom the complaint is lodged. Id. art. 48, at 246. See P. VAN DiJK \& G. VAN Hoof, supra note 49, at 111-29; Boyle, supra note 98 , at 137 . In practice, most complaints that are judged to be adimissible by the Commission ultimately appear before the European Court. Boyle, supra note 98, at 148-49. Member states are required to bring their laws into conformity with the decisions handed down by the European Court of Human Rights. ECHR, supra note 10, art. 53, at 248; Bartsch, supra note 97, at 199. For a general discussion of the obligations of a meinber state to implement a decision of the European Court, see J. Merrills, The Development of INTERnational LAW By the European COURT OF HUMAN RIGHTS 11-19 (1988). Signatory states are obligated to secure the rights of the ECHR under articles 1, 5(5), and 13. ECHR, supra note 10, at 224, 228, 232. They are bound by decisions of the Council bodies by articles 32(4) and 53. Id. at 242, 248. Signatories must report their coinpliance ineasures when so requested under article 57. Id. at 250.

100. The Committee of Ministers is a third branch of the ECHR, but has duties unrelated to the ECHR. P. VAN DIJK \& G. VAN HOOF, supra note 49, at 27-29.

101. Id. at 456.

102. Dowrick writes that: "Following an adverse judgement, defendant states have without exception eventually fulfilled their international obligations and coinphied with its terms, via executive measures which can be inore rapidly effected, or by national legislation which may take years." Dowrick, supra note 25, at 889. See also, Waldock, The Effectiveness of the System Set $U_{p}$ By the European Convention on Human Rights, 1 HuM. RTS. L.J. 1 (1980) (success and effectiveness of Convention possible only through interpretations in do1nestic law consistent with intent of convention). Professor Rusen Ergec has suggested that the high visibility of the decisions of the court in the European inedia helped secure the coinpliance of meinber states. Conversation with R. Ergec, Professor at Frec University of Belgiuin, Copenhagen, Deninark (July 29, 1989); P. VAN DIJK \& G. VAN Hoof, supra note 49, at 455-60; Boyle, supra note 98, at 149-50.

103. ECHR, supra note 10, art. 1, at 224; P. VAN DIJK \& G. VAN Hoof, supra note 49, at 3 , 377-78.

104. Under the ECHR a complainant must exhaust all effective domestic reinedies before bringing his complaint before the Europcan Coininission. ECHR, supra note 10, arts. 26, 27(3), at 238. See F. Castberg, The European Convention on Human Rights 40, 43 (1974); J. Fawcett, supra note 25 , at $355-62,368$. However, remedies that are certain to be ineffective need not be pursued. See P. VAN DIJK \& G. VAN HOOF, supra note 49, at 74-75. On the requireinent of exhaustion of local rcmedies before pursuing a claim at the international level, sec Claim of Finirish Shipowners, (Finland v. Great Britain) 3 U.N. R. Int'l Arb. Awards 1479 (1934) (Finland could bring 
itself. 106 Britain has not incorporated the ECHR itself, and has not created domestic law analogues to all the rights guaranteed by the ECHR. Britain's failure to give domestic effect to the ECHR or provide domestic law alternatives ineans that an individual may argue rights under the ECHR before the European Court of Human Rights in Strasbourg, but that Britain's donnestic courts are not required to consider any arguments directly arising under the ECHR. ${ }^{107}$

2. Privacy Rights Protected by the ECHR. Article 8 of the ECHR secures a right of privacy in the home, family, and correspondence. Specifically, article 8 of the ECHR provides:

(1) Everyone has a right to respect for his private and family life, his home and his correspondence.

(2) There shall be no interference by a public authority with the exercise of this right except such as is im accordance with the law and is necessary in a deinocratic society in the interests of national security, public safety or the economic well-being of the country, for the prevention of disorder or crime, for the protection of health or morals, or for the protection of the rights and freedons of others. ${ }^{108}$

The European Court of Huinan Rights has given article 8 a broad reading. ${ }^{109}$ Article 8 has been used to vindicate privacy rights in the home, ${ }^{110}$

claim in international legal forum for unauthorized use of Finnish ships by Great Britain during World War I since remedies in British War Coinpensation Court no longer available).

105. Cyprus, Iceland, Ireland, Malta, Sweden, and the United Kingdom. J. FAWCETT, supra note 25, at 5-21. But $c f$. A. DRZEMCZEWSKr, EuROPEAN HUMAN RIGHTS CONVENTION IN DOMESTIC LAw 304-22 (1983) (Denmark, Iceland, Ireland, Liechtenstein, Malta, Norway, Sweden, and United Kingdoun do not accord ECHR domestic status). Nevertheless, a signatory state nuay assert that the substance of its doniestic law is in compliance with the ECHR, without actually enabling the specific guarantees of the convention. J. FAWCETT, supra note 25, at 20.

106. Although the literal language of articles $5(5)$ and 13 suggest that doniestic effect be accorded the ECHR, this lias not been the practice under the ECHR. P. VAN DUK \& G. VAN Hoof, supra note 49, at 4-5; see also F. CAstBERG, supra note 104, at 13-14.

107. See P. VAN DIJK \& G. VAN Hoor, supra note 49 , at 10-13.

108. ECHR, supra note 10 , art. 8, at 230 . One sliould note that the protection of privacy in the hoine is somewhat limited, given the scope of article $8(2)$ exceptions. See P. VAN DIJK \& G. VAN HoOF, supra note 49, at 294-95. The exceptions clause has less effect on the proteetion of correspondence and family life. Id. Governmental concerns, such as the prevention of crime and national defense, may justify an invasion of one's privacy in the home do not arise as often in the context of correspondence or family relations. Finally, one should note that article 8 does not protect all aspects of privacy-nondisclosure of information and protection of likeness, for example, are protected under article 10. Id. at 283.

109. Article 8 was derived in part from the Universal Declaration of Human Rights, which recognizes a riglit of privacy. The relevant provision of the Universal Declaration provides that: "No one shall be subjected to arbitrary interference with his privacy, family, hoine, or correspondence, nor to attacks upon his honour and reputation. Everyone has the right to the protection of the law against such interference or attacks." G.A. Res. 217A (II1), 9 U.N. GAOR at 71 art. 12, U.N. Doc. A/810 (1948); see also J. FAWCETT, supra note 25, at 211. Although article 8 reaches governinental infringements of privacy, it is an open question as to whether it creates government hability for private invasions of privacy that are not compensated under existing domestic law. A 
family rights (including a right of parental access), ${ }^{111}$ abortion and other reproductive rights, ${ }^{112}$ and certain freedoms from the disclosure of information. ${ }^{113}$ Many of the cases arising under article 8 have been brought against Britain, ${ }^{114}$ and all of these involved official government actions that were sanctioned by domestic statute or common law, but that arguably were inconsistent with Britain's article 8 obligations.

In applying the substantive provisions of article 8(1), the European Court allows the signatory state to justify facially inconsistent statutes or common law, if possible, under article 8(2). ${ }^{115}$ The article $8(2)$ exceptions clause allows the state to interfere witl privacy rights under three conditions: the interference must be prescribed by law; 116 the law must be sufficiently clear so that a citizen can observe its dictates; ${ }^{117}$ and finally, the law must be "necessary in a dennocratic society." 118 The court

small extension of existing precedents on article 8 would allow a holding that the article reaches essentially private invasions of privacy. One need only assert that article 8 creates not only negative prescriptions on government action, but positive duties to secure privacy rights against unofficial incursion. See J. MERR1LIS, supra note 99, at 95-96. Under the doctrine of Drittwirkung, a government may be hable for private actions violative of the ECHR, when such actions are tolerated under domestic law and thus at least tacitly consented to by the signatory government. See P. VAN DIJK \& G. VAN Hoof, supra note 49, at 284-85. The theory of Drittwirkung has not been expressly rejected in the context of article 8 . For a general discussion of the theory underlying the doctrine of Drittwirkung, see id. at 13-18. However, the European Court views article 8 principally as a protection against government imvasions of privacy. Id. at 284.

110. See J. FAwCETT, supra note 25, at 226-28.

111. See id. at 216-26.

112. See P. VAN DuK \& G. VAN HoOF, supra note 49, at 287. But cf. J. FawceTt, supra note 25 , at 214 ("Article 8(1) cannot be interpreted as meaning that pregnancy and its termination are, as a principle, solely a matter of the private life of the mother.").

113. See P. VAN DiJK \& G. VAN Hoof, supra note 49, at 283.

114. See L. Pettiti, The European Machinery on Human Rights 10-11 (1987). A rationale for this phenomena may be the lack of domestic consideration of privacy claims. See Boyle and Rice v. United Kingdom, 10 Eur. Hum. Rts. Rep. 425 (1988); R. v. United Kingdom, 10 Eur. Hum. Rts. Rep. 74 (1987); Silver v. United Kingdom, 5 Eur. Hum. Rts. Rep. 347 (1983); Dudgeon v. United Kingdom, [1982] 4 Eur. Hum. Rts. Rep. 149 (1981).

115. Some would argue that the article 8(2) exceptions clause takes away most of what article 8 (1) conveys, at least with respect to the protection of privacy in the home. See J. FAwCETT, supra note 25, at 226-27. See also Klass v. Federal Republic of Germany, [1979-80] 2 Eur. Hum. Rts. Rep. 214, 231-37 (1978) (the Europcan Court approved a German law allowing wiretaps; after examining the language of article 8, the purpose of the law, and tlie oversights provided by the law, the European Court concluded that Germany liad a legitimate purpose consistent with article 8(2) and that the means used to effect that purpose were consistent witl article 8).

116. See Malone v. United Kingdom, [1985] 7 Eur. Hum. Rts. Rep. 14, 39-42 (1984).

117. See Silver v. United Kingdom, 5 Eur. Hum. Rts. Rep. 347, 371-73, 376-77 (1983). Specifically, a law must be "accessible" and the potential sanctions for tlie law's breach must be "foreseeable." See Gillow v. Umited Kingdóm, 11 Eur. Hum. Rts. Rep. 335, 350 (1989); Sunday Times v. United Kingdom, [1979-80] 2 Eur. Hum. Rts. Rep. 245, 271 (1979).

118. Silver, 5 Eur. Hum. Rts. Rep. at 376. The test is not wliether a given law or practice is desirable or administratively convenient, but whether it is required in order to aclieve legitimate state purposes. See id. at 376-77. See also J. MERRILls, supra note 99, at 144-49 (discussion of the 
tends to use the practices of the signatory states to determine whether a given practice meets this last criteria. ${ }^{119}$ However, state practices cannot override the express provisions of the ECHR. The Court narrows the "margin of appreciation" granted to member states when regulated activity imphicates core privacy rights. ${ }^{120}$ Article 8 does not confer an absolute right of privacy. It does, however, provide substantial protection to mdividual autonomy.

3. Article 8 in the Domestic Courts of Britain. The United Kingdom does not give domestic effect to the ECHR. ${ }^{121}$ British constitutional theory allows the use of international treaties only to interpret ambiguous parliamentary enactments and to clarify the common law. International treaties, mcluding the ECHR, are not automatically incorporated into domestic British law. Lord Denning provided a succinct restatement of the status of the ECHR in Enghish law:

European Court's interpretation of the "necessary in a democratic society" language in a number of contexts).

119. See Dudgeon v. United Kingdon, [1982] 4 Eur. Hun. Rts. Rep. 149, 167 (1981). The Rees Case is also illustrative of this practice. Rees v. United Kingdoun, [1987] 9 Eur. Hum. Rts. Rep. 56, 65-68 (1986) (United Kingdom not obliged to follow examples of other signatory states relating to recognition of new sex for transsexuals in public records). See also Tyrer v. Umited Kingdom, [197980] 2 Eur. Hum. Rts. Rep. 1, 9-12 (1978) (the Court used the "commonly accepted standards" of the nember states of the Council of Europe to determine whether the bircling policy of the Isle of Man was a degrading puinishment for purposes of article 3 of the ECHR).

120. J. MERRILLS, supra note 99 , at 148 . When regulated behavior is at the heart of a protected right, the European Court will require a slowing of strict necessity to justify the burden on the individual's exercise of the right. As the interest becomes nnore tenuously connected with the essential functions of the right, the court is more tolerant of government interferences. This is done through the "margin of appreciation" given the defendant state. The margin of appreciation is at its greatest when questions of inorals are implicated, because questions of norality are subjective and contextual. Dudgeon, [1982] 4 Eur. Hum. Rts. Rep. at 164 (1981); see also Sunday Times, [1979-80] 2 Eur. Hum. Rts. Rep. at 275-76 (1979) (norals are left to state, except when the result is inconsistent with the practices of other states or with the existence of the right in question); Handyside $v$. United Kingdom, [1979-80] 1 Eur. Hum. Rts. Rep. 737, 753-55 (1976) (discretion granted to states in matters of morality, but European Court has final say as to whether restriction is "reconcilable with [the] freedoni[s]" secured to individuals under the ECHR). There is an exception to this general rule:

However, not only the nature of the aim of the restriction but also the nature of the activities involved will affect the scope of the unargin of appreciation. The present case [on lounosexual sodoiny] concerns a most intimate aspect of private life. Accordingly, there nust exist particularly serious reasons before interferences on the part of the public autliorities can be legitimate for the purposes of article 8 .

Dudgeon, [1982] 4 Eur. Hum. Rts. Rep. at 165. The conclusion is that public authorities are given great discretion over questions of morality, except when the regnlations impinge on an essential protected interest under the ECHR. In determining whether an interest is at the core of a given right, the nature of the right and the practice of the signatory states are considered. Tyrer v. United Kingdom, [1979-80] 2 Eur. Hum. Rts. Rep. 1, 10 (1978).

121. W. PRATT, supra note 23 , at 87. 
The position, as I understand it, is that if there is any ambiguity in our statutes or uncertainty in our law, then these courts can look to the convention as an aid to clear up the ambiguity and uncertainty, seeking always to bring them into harmony with it. Furthermore, when Parliament is enacting a statute or the Secretary of State is framing rules, the courts will assume that they had regard to the provisions of the convention and intended to make the enactment accord with the convention, and will interpret them accordingly. But I would dispute altogether that the convention is part of our law. ${ }^{122}$

Thus, the supremacy of Parliament lias led to problems concerning the incorporation of the ECHR in Britain-problems that arise because domestic law does not imdependently secure all ECHR riglits. ${ }^{123}$ At best, privacy serves as a canon of statutory construction; ${ }^{124}$ this canon is insufficient to meet the requirements of article 8.

One argument for the domestic incorporation of article 8 of the ECHR is that the article represents a codification of customary international law. Customary imternational law, ${ }^{125}$ througli incorporation by the practice of sovereign nations, is a part of the domestic law of England. If a treaty represents the codification of pre-existing norms of international behavior, or if a treaty later coines to represent the current standard of customary international law, then riglits under suclı a treaty would be justiciable in donestic Britisli courts. ${ }^{126}$ Thus, article 8 of the

122. R. v. Chief Immigration Officer, Heathrow Airport, ex parte Bibi, [1976] I W.L.R. 979, 986 (C.A.).

The rights established under treaties are nonjusticiable in the courts of England, unless the treaty implicates the Crown's power of war and peace, or Parliament enables the language of the treaty. See Higgins, supra note 94, at 134-35, 137. The lack of domestic effect is related to the manner in which treaties are negotiated and ratified. See id. at 130. Traditionally, the Crown, and not Parliament, negotiated, concluded, and ratified trcaties. See id. at 124. In modern times, the ratification of a treaty is principally an executive function, although treaties are "laid before" Parhament before being ratified. Id. Even today treaties are officially concluded on behalf of the "Crown" by the Secretary for Foreign and Commonwealth Affairs. See id. at 123. Since the Government exercises broad control over the legislative pronouncements of the House of Commons, it makes little sense to refuse to recognize the treaty domestically. The absence of any separation of powers in Britain makes formalism in the incorporation of treaties into domestic law redundant at best. See generally P. ATIYAH \& R. Summers, supra note 20, at 299-306 (describing Prime Minister's control over the House of Commons' legislative schedule).

123. Higgins, supra note 94 , at 129 ; Ryan, supra note 56 , at 8 , col. 1 .

124. See supra notes $84-92$ and accompanying text.

125. A succinct definition of the sources of international law may be found in article 38 of the Statute of the International Court of Justice, opened for signing June 26, 1945, 59 Stat. 1055, T.S. 993, 3 Bevans 1179. However, no hist of the sources of international law can be exhaustive. The content of customary international law is constantly evolving based on present state practice. See McDougal, The Hydrogen Bomb Tests and the International Law of the Sea, 49 AM. J. INT'L L. 356, 357-58 (1955).

126. See Higgins, supra note 94, at 125; see also Trendtex Trading Corp. v. Central Bank of Nigeria, [1977] 1 Q.B. 529 (C.A.). 
ECHR, if a codification of customary international law, would be incorporated into English law.

There are two competing doctrines concerning the incorporation of international law into domestic British law: the incorporation theory and the transformation theory. The incorporation theory holds that as international law changes, British law changes with it, even if cases exist that apply the old rule. ${ }^{127}$ This theory reflects a inomist account of lawthere is only one law that operates on all persons. ${ }^{128}$

The transformation theory holds that changes in international law must be incorporated either by parliamentary action or by the House of Lords. Under the transformation approach, Britain does not automatically adopt changes in customary international law. This theory reflects a dualist theory of law-municipal law and international law are totally separate systems. International law applies only to states, and thus cannot alter domestic law. ${ }^{129}$ Under this theory, only if the doinestic government ratifies article 8 of the ECHR will it apply internally relating to private persons.

In Trendex Trading Corp. v. Central Bank of Nigeria, the Court of Appeal adopted the imcorporation theory. ${ }^{130}$ Two judges opined that clianges in international law were directly assimilated into British law, even if such changes conflicted with earlier cases decided by the Court of Appeal or House of Lords. ${ }^{131}$ Lord Denning reasoned that because international law embodies no doctrine of case precedent, and because English law requires the domestic courts to apply international law, domestic law must reflect changes in international law, even if these changes are inconsistent with earlier domestic precedents. ${ }^{132}$

Given the incorporation theory of international law, it is theoretically possible that the ECHR (and article 8) could be incorporated into

127. Trendtex, [1977] 1 Q.B. at 553; see also Collier, Is International Law Really Part of the Law of England?, 38 INT'L \& COMP. L.Q. 924, 931-34 (1989) (discussing adoption of incorporation theory in the 1970s); Duffy, English Law \& The European Convention on Human Rights, 29 INT'L \& CoMP. L.Q. 585, 599-601 (1980) (discussing Trendtex and the incorporation approach).

128. For an excellent discussion on the currency of inonist and dualist theories of law and the incorporation of international law in England, see Collier, supra note 127, at 924-26.

129. See id. at $925-26,928-30$.

130. [1977] 1 Q.B. 529 (C.A.). In adopting this theory, it largely ignored an earlier case, $R . v$. Secretary of State for the Home Department, ex parte Thakrar, [1974] 1 Q.B. 684, 701, which seenied to adopt the transformation theory: "As between these two schools of thought [incorporation and transformation], I now believe the doctrine of incorporation is correct." Trendtex, [1977] 1 Q.B. at 554.

131. Trendtex, [1977] 1 Q.B. at 554, 577 (Lord Denning and Shaw L.J. agreed that the incorporation theory was correct and that old cases interpreting international law could be overridden by subsequent developnents in international law).

132. Id. at 554; Collier, supra note 127, at 932. 
English law without parliamentary action by arguing that the ECHR reflects customary principles of international law. However, the requirements necessary for success in this endeavor are difficult to satisfy. ${ }^{133}$ A plaintiff must show that respect for privacy lias achieved strict observation in the practice of nation states. ${ }^{134}$. Altliough some obligations-such as the prohibition on torture-create binding norms of behavior on states, ${ }^{135}$ privacy lias not yet reaclied this level of recognition and the domestic courts have not found the argument that the ECHR (either in whole or in part) embodies customary international law persuasive. ${ }^{136}$

A more successful argument for the recognition of article 8 by the British domestic courts is the principle of legitimate expectation. ${ }^{137}$ The principle derives from an administrative law concept similar to the right to be heard under the due process clause of the Umited States Constitution and the private contract law notion of promissory estoppel. ${ }^{138} \mathrm{Le}-$ gitimate expectation covers rights not necessarily recognized at law, but rights that have a reasonable basis in the law. ${ }^{139}$ Thus, there is no legal right to the vindication of the interest, but rather a willingness by courts to allow the vindication of reasonable expectations when those expectations are not inconsistent witl statutory law. ${ }^{140}$

133. On the difficulties in proving that the ECHR reflects customary international law, see Duffy, supra note 127, at 599-605 (discussing the incorporation of international law into British law and the requirements that must be satisfied before the ECHR is considered "customary international law").

134. The problem is that, "despite the international (and national) instruments, instances of human rights violations are all too frequent, thus weakening the argument based on state practice stricto sensu." Id. at 602.

135. Id. at 604-05.

136. See infra notes $144-50$ and accompanying text.

137. See Schmidt v. Secretary of State for Home Affairs, [1969] 2 Ch. 149, 170 (C.A.); AttorneyGeneral of Hong Kong v. Ng Yuen Shiu, [1983] 2 A.C. 629, 636 (P.C.). For a more recent discussion of these cases and of the principle of legitimate expectations, see Chundawadra $v$. Inmigration Appeal Tribunal, 1988 Imm. A.R. 161, 169, 170.

138. For a discussion of "legitimate expectation" paralleling United States' notions of due process, see Saleini v. MacKellar (No. 2), [1977] 137 C.L.R. 396, 404-05, 422-23 (Austl.). Although, this is an Australian case, the British Court of Appeal cited the case in Chundawadra. Chundawadra, $1988 \mathrm{Imm}$. A.R. at 170. For the American formulation of the due process notion, see Board of Regents v. Roth, 408 U.S. 564, 577 (1972) ("He must have more than a unilateral expectation of it [the benefit]. He must, instead, have a legitimate claim of entitlement to it.") See also REstatement (SECOND) OF CoNTRACTS $\S 90$ (1981). The analogy to promissory estoppel is helpful by way of loose analogy. Promissory estoppel operates primarily in the private sector rather than the public sector. At bottom, "legitinate expectation" is a doctrine of British adininistrative law meant to secure the reliance interests of those whose activities the government regulates in one way or another.

139. See Chundawadra, $1988 \mathrm{Imm}$. A.R. at 170 (quoting $N g$ Yuen Shiu, [1983] 2 App. Cas. at 636 (P.C.)).

140. See id. at 173. The doctrine is discretionary in its application. See id. at 170 (quoting $\mathrm{Ng}$ Yuen Shiu, [1983] 2 App. Cas. at 636 (P.C.)). 
A legitimate expectation may arise from the actions or statements of a public authority. ${ }^{141}$ In recent years, litigants have argued that based on current government policy, they have a "legitimate expectation"142 of domestic protection of their article 8 rights. The results liave been largely disappointing.

Chundawadra v. Immigration Appeal Tribunal ${ }^{143}$ illustrates the argument that the principle of legitimate expectation sometimes requires the explicit imcorporation of article 8 into domestic law. Chundawadra presented the novel argument that he had a "legitimate expectation" that the Home Secretary would take article 8 into account in assessing his immigration status. ${ }^{144}$ The immigration statutes in question included a requirement that the person deciding the case consider the "public good," 145 and Chundawadra argued that the "public good" included Britain's compliance witl its international obligations.

After laboriously examining the present scope and history of legitimate expectation, the Court of Appeal unflinchingly rejected its application to rights arising under article 8 on the facts presented. ${ }^{146}$ The court concluded that because Parliament had not incorporated article 8 into British domestic law, an mdividual could not maintain a legitimate expectation that public authorities considered article 8 .

Not all the Lords were so quick to reject tlie legitimate expectation argument. Lord Slade's concurrence would have reserved the determination of the outcome if the Secretary of State had a clearly establislied policy of considering the ECHR in exercising his discretionary statutory authority. ${ }^{147} \mathrm{He}$ believed that it was possible for a legitimate expectation to arise when a governmental agency, exercising discretionary decision-

141. Id. at 171 (quoting Council of Civil Serv. Unions v. Minister for the Civil Serv., [1985] 1 App. Cas. 374, 401 (H.L.)).

142. See infra note 150 and accoinpanying text.

143. [1988] Imm. A.R. 161 .

144. Id. at 169 .

145. Immigration Act, 1971, ch. 77, § 3(5)(b).

146. The Court stated the following:

Here there is an international treaty; the Government of the United Kingdoun has acceded to it but it is not enbodied in our domestic legislation, and indeed, whether it should be is the subject of a good deal of discussion. But it is not and because it is not it nay not be looked at or prayed in aid in relation to matters in these courts save when a question of ambiguity in a statute or other legal text arises. That not being the case here, it inay not be looked at all and no expectation that it should be followed can arise. ... it is not appropriate to introduce the Convention into the law of England by the back door of legitimate expectation when the front door is firmly barred.

Chundawadra, [1988] Imm. A.R. at 174.

147. Id. at 175. See, e.g., Solnasundarum v. Entry Clearance Officer Colomobo, [1990] Imm. A.R. 16, 20 ("[W] power to refer to the Convention on Hunan Rights or any other Convention. However there inay be consideration of Conventions in the exercise of an executive discretion."). 
making power, had an established policy of considering article 8 in the decisionmaking process.

Although Lord Slade's observation appears promising, it does not significantly alter the status of the ECHR in Britisil domestic courts: absent parliamentary reference to article 8 , the article and privacy are only considered by the courts when they construe ambiguous statutes. ${ }^{148}$ The courts have held that a government minister is not required to consider the treaty obligations of the United Kingdom when exercising discretionary authority. ${ }^{149}$ Yet a decisionmaker conld adopt a unilateral pohicy requiring the consideration of article $8-$ or any other provision of the ECHR. Under these circuinstances, the doctrine of legitimate expectation would allow the consideration of article 8 by the domestic courts. ${ }^{150}$ Legitimate expectation demonstrates one way to incorporate article 8 . However, the incorporation of article 8 in this manner not only will be pieceineal, but also will be subject to parliamentary reversal by statute.

4. The Interaction of the European Court and the British Domestic Courts: Attempts to Vindicate Article 8 Rights. Because of the difficulties encountered in vimdicating article 8 rights im the doniestic courts of Britain, sonie British citizens have sought relief in the European Court of Human Rights by arguing a breach of the right of privacy protected by article 8. As a consequence, the European Court, doniestic British courts, and Parliament have worked together to bring British law into conipliance with article 8. Custody and correspondence nuatters present two types of cases that demonstrate not only that Britain is not fulfilling its obligations under article 8, but also that the European Court can be a

148. See infra notes 157-62 and accompanying text.

149. R. v. Chief Immigration Officer, Heathrow ex parte Bibi, [1976] 1 W.L.R. 976,984 (C.A.).

150. A 1987 case authored by Judge Taylor lends support to the limited usefulness of the doctrine of legitimate expectation in the context of privacy. R. v. Secretary of State for the Home Dep't ex parte Ruddock, [1987] 1 W.L.R. 1482 (Q.B.) held that when a warrant for a telephone wiretap was issued, those subject to it could claim a legitimate expectation that the declared policies of the Home Secretary would be followed, unless a public change of such policies was announced. A member of a nuclear disarmament campaign who had her phone tapped claimed that the procedures followed to authorize the tap violated the Home Department's publicly adopted guidelines. Id. at 1484-88, 1493. While invoking article 8 and Malone v. United Kingdom, [1985] 7 Eur. Hum. Rts. Rep. 14 (1984) as background considerations, Ruddock's barrister founded his argument on the doctrine of legitimate expectatiou. Id. at 1493-97.

It was argued that the privacy interest uuder article 8 showed an injury sufficient to predicate the invocation of the legitimate expectation doctrine. Id. at 1493-94. Ruddock accepts in large part the approach suggested by Lord Slade in Chundawadra. See Chundawadra, $1988 \mathrm{Imm}$. A.R. at 17576. The trend is to allow the indirect vindication of privacy interests through legitimate expectation when the facts will evidence the breach of an affirmative promise or policy by a government agency or officer. Id. at 1497. 
necessary alternate forum for British citizens to pursue their autonomy claims.

Although British citizens may pursue their claims in the European Court, from a national perspective, this is hardly an ideal forum. The process allows a foreign tribunal to scrntimize the act of the British Parhament for violations of basic human 'rights. ${ }^{151}$ British cultural values may be unduly discounted by allowing a foreign tribunal to judge the correct line between individual right and commumity prerogative in Britain. However, if the British government will not pohce itself, the European Court is authorized to assume this responsibility.

In response to European Court decisions, Parliament has reacted positively in some instances by bringing British law into compliance with article 8. Although courts are willing to enforce privacy claims when authorized by Parliament, the courts will not independently apply article 8 . The social costs engendered by this system are high.

a. An example of the British legal system and the European Court interacting: custody cases and article 8 . In cases involving parental rights, the ECHR and article 8 have been used to defend against government actions. These cases arise under the protection of privacy in the family life contained in article 8(1). Problems occur because of the inherent conflict between parental rights and the state's interest in protecting children from unfit or abusive parents.

In $R$. v. United Kingdom, ${ }^{152}$ the European Court found that the discretion given to British local authorities to decide custody matters, coupled with the lack of effective judicial review, constituted a violation of article $8 .{ }^{153}$ Because the hearings in question set in motion a process that could result in the total severance of all parental rights, the European Court found that article 8 required meamingful participation by custodial parents informed of the possible consequences of the local authority's action. The court also held that the local authority's decisions must be subject to timely judicial review. ${ }^{154}$ Although article 8(2) authorized in-

151. P. ATTYAH \& R. SUMmers, supra note 20, at 269-71, 298-99.

152. [1988] 10 Eur. Hum. Rts. Rep. 74 (1987).

153. Id. at 46, 48-50 (the facts and legal analysis for $R$. $v$. United Kingdom are in part reported in W. v. United Kingdom, [1988] 10 Eur. Hum. Rts. Rep. 29 (1987); an explanatory note appears at 10 Eur. Hum. Rts. Rep. 76.).

154. Id. at 49-51, 80. A related, but different, interest was at issue in Gaskin v. United Kingdom, [1990] 12 Eur. Hum. Rts. Rep. 36, 38-43 (1989). Gaskin involved a request for documents related to Gaskin's childhood. Mr. Gaskin, as a child, had been in the custody of various social services departments following the death of his mother. Id. at 38. The Liverpool City Council refused to provide Mr. Gaskin with access to his files, which included statements provided on a confidential basis. Id. at 39. The European Court of Hunan Rights held that the City Council violated article 8 by refusing to provide Mr. Gaskin with his personal records. The Court concluded that personal 
terference with parental rights of access, the court held that the right to be heard and participate in such hearings was essential to meeting the "necessity" prong of the article 8(2) exceptions clause. ${ }^{155}$ Thus, the case was as much about procedural fairness as it was about parental rights.

In the wake of $R$. v. United Kingdom, Parhament reforned its custody laws to bring British law into compliance with article 8.156 However, the courts remained unwilling to consider independently article 8. Despite the existence of clear precedents from the European Court, the British judiciary continues to apply unambiguous parliamentary enactments without regard to privacy interests; however, if Parhament itself takes article 8 into consideration when passing a statute, the courts will directly address the privacy claims.

A recent case, In re K.D. ${ }^{157}$ illustrates the judiciary's willinguess to address privacy claims when authorized to do so by Parliament. The case presented the issue of whether a clearly unfit mother could continue to exercise parental riglits. The court deined the teenage inother access to her children until she severed contact between her boyfriend and the children. ${ }^{158}$ In approaching this problem, the Law Lords often referred to the principles embodied in article $8 \mathrm{im}$ an attempt to resolve the conflict between English law and the requirements of the ECHR. 159

The reason the Lords considered article 8 was, in part, due to $R$. $v$. United Kingdom-the custody case in which Britain was found to have violated article $8 .{ }^{160}$ The motlier's barristers presented legislative history to the House of Lords that indicated parliamentary concerns similar to, if

files regarding "family life" that are maintained by the government could not be arbitrarily kept confidential. Id. at 50 . Gaskin is one more example of the British government's failure to properly implement article 8, illustrating again the need for the domestic incorporation of article 8 .

155. Id. at 50-53. See supra text accompanying note 108 for the text of the article 8(2) exceptions clause. $R$. v. United Kingdom was one of several cases contemporaneously decided by the European Court of Human Rights reviewing Britain's custody laws. [1988] 10 Eur. Hum. Rts. Rep. 1-122 (1987).

156. M. v. H., [1990] 1 App. Cas. 686, 722 (H.L.).

157. [1988] 1 App. Cas. 806 (H.L.).

158. Id. at 813-15 (speech of Lord Oliver, setting out facts of case).

159. "In my opinion there is no inconsistency of principle or application between the English rule and the Convention mle. The best person to bring up a child is the natural parent." Id. at 812 . Lord Oliver seems to apply English law, but also considers the requirements imposed under article 8. For example, Lord Oliver stated that:

Although this [the R. v. United Kingdom case from the European Court] is not binding upon your Lordships, the United Kingdom is, of course, a party to the Convention for the Protection of Human Rights and Fundamental Freedoms and it is urged that it is at least desirable that the domestic law of the Umited Kingdom should accord with the decisions of the European Court of Human Rights under the Convention.

Id. at 823. Lord Oliver then proceeds to square domestic law with Britain's article 8 obligations. Id. at $823-25$.

160. In response to $R$. v. United Kingdom, Parliament modified British law to refleet the European Court's decision. See infra note 163; [1988] 10 Eur. Hum. Rts. Rep. 74 (1987). 
not coextensive with, rights guaranteed under article 8. Although the Lords found that the procedures used in the custody hearing complied with both English law and the duties imposed by article 8,161 reference to article 8 is, in itself, surprising. The House of Lords felt it necessary to address article 8 directly, even though it could not bind the Lords.

The congruence of article 8 and domestic law on the delineation of parental rights legitimated judicial reference to the article. Because British statutory and common law characterized parental access as a fundamental interest, the Law Lords were not preempting parliamentary decisionmaking by independently giving effect to a legal provision of the ECHR. ${ }^{162}$ Thus, the ECHR may be relevant in modifying or applying domestic law-especially if the article 8 right in question is squarely addressed under statutory law.

Although some privacy rights are vindicated by the domestic British courts, $R$. v. United Kingdom is emblematic of the social cost created by the British system. ${ }^{163}$ The system forced the parent to go through time consuming (and largely useless) appeals in the domestic courts before permitting recourse to the European Court. The British judiciary views this as a necessary evil. Judicial deference preserves the necessity of par-

161. Id. at $828-30$.

162. In Re K.D., [1988] 1 App. Cas. at 811-13, 823-25.

163. Id. M. v. H. demonstrates the Lords' limited use of article 8 as a tool in statutory interpretation. In $M$. v. $H$., a biological father demanded rights of parental access to a child born outside of wedlock. British custody law did not recognize a right of access for unmarried biological parents, whereas case law from the European Court suggested that article 8 required some legal process before such a denial of parental access could be permitted. Id. at 713-18. Under the terms of the custody statute, the British domestic courts could not review the merits of local custody officials' decisions. Id. at 718-21. Counsel for the father suggested that the previous British cases were wrongly decided, especially in light of recent decisions of the European Court interpreting artiele 8. Id. at 717-18.

The House of Lords, per Lord Brandon, squarely rejected the application of article 8. They held that article 8 cannot be applied if the result would be inconsistent with domestic statutory and case law. Id. at 721. The bench recognized that their decision was inconsistent with Britain's international obligations under the ECHR. Nevertheless, the Lords refused to modify domestie law to accommodate the regnirements imposed under article 8: "Parliament has not, in the statutes relating to children in the care of local authorities ... given full effect to certain provisions of the Convention, and has in that respect failed fully to comply with the international obligations of the Urited Kingdom as a party to it." Id. at 721-22. Lord Brandon's speech concluded by observing that Parliament amended British domestic law in anticipation of the R. v. United Kingdom decision by the European Court and that Parliament may do so again to avoid the possibility of being sanctioned in the event that the father took his case to the European Court. Id. at 722.

The gravamen of $I n$ Re K.D., [1988] 1 App. Cas. 806 (H.L.), is thus limited: Where domestic law is not clearly consistent with the ECHR, the Honse of Lords defers to Parliament to make whatever changes they deem necessary. While the efficiency of Parliament in addressing such problems when they arise inakes this a workable system, one cannot help but question the faimess of this approaeh to individual litigants. See generally P. ATIYAH \& R. SUMmERS, supra note 20, at 299-306 (describing the efficiency of parliamentary law reform). 
liamentary reforms and creates an impetus for parliamentary action. ${ }^{164}$ If legislative reform is more thorough and more effective than piecemeal judicial reform, then there is nothing problematic with this approach. ${ }^{165}$ However, this argument presupposes that Parliament will vindicate minority autonomy interests. This premise is open to question: Why should a democratic, majoritarian body respond to the autonomy demands of distinct insular minorities? The question of Parhamentary sensitivity to unrepresented groups remains unanswered.

In Re K.D. and R. v. United Kingdom do not imcorporate the ECHR as a whole. Only if a right already exists under domestic law may provisions of the ECHR and the case law interpreting it be considered by a British court applying domestic law. This inode of interpretation gives some provisions of the ECHR the status of a principle of constructionas tools of statutory interpretation. The Law Lords will harmonize domestic law and obligations under the ECHR, but they will not allow the ECHR to preempt conflicting domestic legal norms.

b. An example of article 8 precipitating unilateral reform: the correspondence cases. Like parental rights, the ability of individuals to communicate with each other without government surveillance is an important aspect of privacy that is necessary for a free society. British domestic courts also lave refused to vindicate article 8 rights to privacy for personal correspondence absent express or imphicit parliamentary authorization. However, the interaction between the European Court and the British legal system that occurred (and is still ongoing) in the custody cases is absent in the correspondence cases.

In Boyle and Rice v. United Kingdom, ${ }^{166}$ the European Court held that the United Kingdom's practice of opening prisoners' mail addressed to their legal representatives constituted a breach of article 8. ${ }^{167}$ The British government reformed its policies before the decision was handed down, more or less admitting that its prior practice was not in comphance with article 8 . Thus, the European Court and article 8 can precipitate the complete reform of a given area of the law.

164. See infra notes 257-67 and accompanying text.

165. Some say this is especially true in the United Kingdom, where for 400 years the system's reliance on parliamentary reform has arguably worked quite well. Interview with P.S. Atiyah in Durham, N.C. (March 22, 1989). But cf. Rule, Group Says Press Freedom is Declining in Britain, N.Y. Times, Oct. 19, 1990, § A, at 7, col. 1 ("The U.K. with no written constitution and no formal protection of freedom of expression has depended on a tradition of self-restraint by the law-inaking and law-enforcement authorities. The worrying trend toward tighter governmental control shows that these traditional safeguards are no longer workmg and, therefore, no longer adequate [quoting Dr. Frances D'Souza, director of Article 19, a London-based human rights group].").

166. 10 Eur. Hum. Rts. Rep. 425 (1988).

167. Id. at $441-42$. 
c. Parliamentary reaction to cases from the European Court is a poor means of securing compliance with article 8 . The cases presented in this subsection illustrate the effect that the ECHR can have on British domestic law. Without pressure from the European Court, modification of the custody laws and prison rules might never have occurred. Although the dounestic courts can cite inconsistencies with domestic law and the ECHR, they will not ascribe any legal consequences to this conflict absent a parliamentary command. Parliamentary action inevitably follows decisions from the European Court: But why should reform wait on a decision from the Strasbourg court? A review of the article 8 clains on the merits by the British domestic courts prior to review by the European Court makes sense. The British domestic courts are in the best position to interpret their own laws, provided the laws are consistent witl article 8. Additionally, the financial expense and embarrassment of defending a suit before the European Court could be avoided if most claims were decided on the merits in the domestic courts. The present system works, insofar as it brings about reforın, but it fails to the extent that it discourages the aggressive litigation of liuman and political rights.

\section{The Future of a Right of Privacy in Britain}

1. The European Economic Community Adoption of Article 8 in the Commercial Context. Article 8's future as a source of domestic privacy rights is not yet completely determined. Just as the Treaty of Rome (which established the EEC) assumed greater significance with the passage of time, so too could the ECHR. Consider Lord Denning's prophetic observation about the role of the Treaty of Rome in the early 1970s: "[W] $]$ hen we come to matters witl a European element, the Treaty is like an incoming tide. It flows imto the estuaries and up the rivers. It cannot be held back . . ."168 Very few people could have foreseen the complete commercial integration of Europe, which is almost a reality. Likewise, although the ECHR, a charter of basic liuman rights, does not yet liave the ubiquitous presence of the Treaty of Rome, the day when the ECHR directly displaces domestic laws may one day arrive. Although it is far froin a certainty, the ECHR and the institutions implementimg it may also become a source of British domestic law in the same way as the Treaty of Rome.

A more limited implementation of the principles of the ECHR may already liave arrived. The European Economic Community's Court of Justice uses the primciples reflected in the ECHR, and article 8 in partic-

168. H.P. Bulmer Ltd. v. J. Bollinger, S.A., [1974] 1 Ch. 401,418 (C.A.). The supranational character of the EEC has certainly accelerated this process. See supra note 97 and accompanying text. 
ular, as a source of guidelines for permissible community action. ${ }^{169}$ Fundamental rights forin an integral part of the general principles of law that the Court of Justice protects. ${ }^{170}$

Thus, privacy interests are "fundamental rights" recognized and protected in commercial affairs by the EEC. The indirect importation of article 8 in the commercial context by the EEC presents a plausible stimulus to further parhamentary action. As the commercial integration of Europe continues, the ECHR may take on greater significance in the United Kingdoin through EEC law (but only in the commercial context). Eventually, a dichotomy in the domestic rights of individuals may develop between their commercial hives-as governed by EEC law-and their private hives, as governed by British domestic law. Individuals conceivably could enjoy greater protection in the board room than in the bedrooin. At that point, Parhiament would have to consider the wisdom of continunig to refuse to incorporate the ECHR into domestic law.

\section{A Final Comment on Privacy in Great Britain. Great Britain's} international obhgation under the ECHR to vindicate certain privacy interests cannot be dismissed or ignored. Some legally cognizable privacy right-particularly as against the government-is necessary for Great Britain to fulfill its obhigations under the ECHR and the Umiversal Dec-

169. See National Panasonic Ltd. v. Commission of the European Conmunities, 1980 E. Comm. Ct. J. Rep. 2033, 2056-58, [1980] 3 Common Mkt. L.R. 169, 186-87. The formal adoption of the ECHR standards by the EEC would go far toward securing to British citizens in domestic courts. See also P. VAN DuK \& G. VAN HOOF, supra note 49 , at $479-486$ (discussing the interplay between the EEC and the ECHR, and the potential for greater application of the principles of the ECHR by the EEC).

170. P. VAN DIJK \& G. VAN Hoof, supra note 49, at 13. It is relatively well establislied that the ECHR is a source of fundamental principles which are part of Community law: "Similarly, international treaties for tlie protection of human rights, on which the Member States liave collaborated or of which they are signatories, can supply guidelines whicls should be followed within the framework of Community law." Nold, Kohlen, and Baustoffgrosshandlung v. Commission of the European Communities, 1974 E. Comm. Ct. J. Rep. 491, 507, [1974] 2 Comnion Mkt. L.R. 338, 354.

Where a nexus exists between an area ceded to the Community's institutions under the Treaty of Rome and a protected "fundamental right" guarantced by the ECHR, the Community will adjudicate the individual's claim using standards derived from the guarantees of the ECHR. In practical terms, this would suggest that the preemption of doniestic law by the EEC would then lead to the de facto domestic application of the rights protected under ECHR as part of Community law, even in the Umited Kingdom. Community law supersedes inconsistent domestic law, and therefore could crcate a domestic claim to a privacy right similar to article 8. For an example of EEC law superseding domestic law (in Scotland), see Kaur v. Lord Advocate, 1980 Sess. Cas. 319, 336. For a discussion of the implications of the ECHR as a norm of EEC law, see P. VAN DIJK \& G. VAN Hoof, supra note 49 , at $479-86$.

With regard to article 8 in particular, see the statement of the Advocate-General of the Court of Justice in State v. Watson, 1976 E. Comm. Ct. J. Rep. 1185, 1205, [1976] 2 Common Mkt. L.R. 552, 564. Article 8 was relevant in deciding whether an Italian immigration policy violated article 48 of the Treaty of Rome on the free moventent of persons. Id. at 1192-93, 571-72. 
laration of Human Rights. ${ }^{171}$ Parhament's refusal to allow the domestic courts to entertain arguments premised on article 8 ensures the breach of this obligation. Apparently, securing the rights guaranteed under the ECHR is a lower priority for Parliament than mamtaining its traditional prerogative of plenary legislative authority.

Perhaps Britain should continue to abjure mdividual justice in favor of the greater good of reliable Parhamentary reform. ${ }^{172}$ But from an American perspective, this solution seems harsh-if not unjustifiable. ${ }^{173}$ If a society truly beheves in liberty, then it must support liberty for all. The institutional framework of government inust provide distinct subgroups with the opportumity to be heard. Further, if the majority elects to vest rights (as Britain has in acceding to the ECHR), it should ensure that claims to those rights are vindicated regardless of the status of the person who inakes the claim.

\section{Privacy in the United States-The Precarious Balance of Individual Liberty and CoMmunity Preferences}

The transformation of privacy and autonoiny concerns into constitutionally cognizable rights is a relatively new occurrence in the United States. Over the last several decades, the courts liave wrought a revolution in autonomy rights. The tension between individual claims to deference with regard to personal choices and community claims to regulate behavior for the good of all provides the central theine in the historical development of these rights. The competing traditions of liberty maximization and majoritarian delnocratic primciple lave shaped this dialectic.

Unlike Britain, the United States has adopted "privacy" as a useful legal construct. The right of privacy provides Umited States citizens both a substantive right and a procedural mechamisin with which to challenge intrusive government regulations. However, the experience of the United States demonstrates that mere recoguition of the right of privacy is insufficient to vindicate important autonoiny interests. Procedural regularity and clarity in defining the privacy right are integral to its effective vindication by courts. The British systein's approach to privacy, although seriously flawed, possesses both virtues: Privacy rights are clearly defined and the legal process of enforcing those rights is strictly circumscribed. However, certaimty and procedural regularity should not outweigh the

171. See Younger REPORT, supra note 15, at 212. The United Kingdom wins as often as it loses when brought before the European Court; however, its overall record is at best spotty. See supra note 123 and aecompanying text.

172. See infra notes 266-67 and accompanying text.

173. P. ATIYAH \& R. SUMmers, supra note 20, at 229-39; id. at 420-26. 
ultimate goal of vindicating liberty. Britain's reticence to adopt a right of privacy is based on the faulty assumption that a "right of privacy" cannot be predictably and uniformly applied by Courts. ${ }^{174}$ The history of privacy law in the United States demonstrates that tradition could provide a solution to the problen of inclusive rights at the cost of certainty. Tradition could effectively delimit the scope of privacy rights witlout unduly limiting then. ${ }^{175}$ An examination of the American experience with privacy law will amply demonstrate that the British concern for legal certainty need not be sacrificed in order to nore effectively protect the hiberties of the people.

The broad language of the Constitution ostensibly protects individual hiberty fronı governmental encroachment. Concurrently, the Constitution contains a strong infusion of a deniocratic principle that implies majoritarian choiceinaking. Forced to disentangle these contradictory constitutional norins, the Court lias referred to community tradition as a means of validatimg claims of autonomy. ${ }^{176}$ The use of tradition, however, risks a pernicious contamination of liberty by allowing niajoritarian inupulses to regulate unpopular behavior. Even though United States' privacy law utilizes a different institutional paradigm, it suffers froin the same nlalady of the British regime-too much concern for majoritarian preferences, and not enough concern for the competing (niajoritarian) value of individual liberty.

In the United States, privacy rights primarily are vindicated by the federal judiciary, rather than the Congress. Althougli the role of Congress in the developnient of privacy rights lias been far less important than Parliament's role im Britain, Congress lias enacted sonie laws that inuplicate "privacy" imterests. In the 1960s and 1970s, technological advances in infornuation collection and transnission greatly mcreased the potential for government invasion of mdividual privacy rights. In response, Congress enacted laws that created rights and duties with respect to the gathering, nlamtenance, and dissemination of infornation about

174. See Malone v. Metropolitan Police Commissioner, [1979] 1 Ch. 344, 372-73 (Ch.) (broadly worded rights, such as the right of privacy, cannot be predictably applied by courts and therefore should be avoided whenever possible).

175. Both the European Court, see supra notes 115-20 and accompanying text, and the EEC, see supra notes $168-70$ and accompanying text, use tradition to delimit broadly worded rights. Thus, Britain's rejection of article 8 reflects, in part, a rejection of tradition as a meaningful dehmiting principle to cabin judicial decisions. See generally P. ATTYAH \& R. SUMMERS, supra note 20, at 423 (European Court, interpreting a text without standards, issues "mere opmions"). I suggest that tradition can provide meaningful guidance to courts, thus ineeting the British passion for legal predictability and conformity.

176. See Michael H. v. Gerald D., 491 U.S. 110, 122 n.2 (1989) (Justice Scalia says that the existence of laws prohibiting an act excludes that act froin protection under the due process clause; clause protects only "important traditional values"). 
individuals; 177 however, these laws did not focus on individual autonomy. ${ }^{178}$ The task of vindicating autonomy claims remained with the federal judiciary.

In the 1920s, the Supreme Court began to develop a distinct privacy doctrine. ${ }^{179}$ The Court considered deference to individual choicemaking a legitimate object for judicial protection. In the 1960s and 1970s, early precedents from the 1920s were used to expand the right of privacy into a shibboleth capable of overpowering state and federal laws. However, in the 1980s, the Court reexamined its use of the right of privacy and its earher precedents.

Today privacy law in the United States is at a crossroads. The Court ultimately must choose between older cases that emphasize individual rights (placing the burden on the state to justify regulation of individual behavior) and new decisions that emphasize the coinmunity's interest in self-regulation through democratic institutions (placing the burden of proof on the individual to affirmatively establish why the government cannot act as it has). Although the existence of the right of privacy is not in immediate danger, the contemporary Court could severely restrict the scope of the right. The recent developments in United States privacy law deinonstrate that the recognition of a right of privacy did not resolve all problems. How a "right" is implemented may be as important as whether the right is recognized in the first place.

\section{A. The Development of the Right of Privacy in the United States}

State legislatures or the federal Congress could have assumed primary responsibility for the development of U.S. privacy law. Instead, the federal judiciary, imsulated from the rigors of partisan politics, has as-

177. These include: The Freedom of Information Act, Pub. L. No. 89-487, 80 Stat. 250 (1966), amended by Pub. L. No. 93-502, 88 Stat. 1561 (1974), (codified at 5 U.S.C. § 552 (1988)) (requires government disclosure of information gathered and collected in certain matters); the Right to Financial Privacy Act, Pub. L. No. 95-630, 92 Stat. 3697 (1978) (codified at 12 U.S.C. $\$ \S 3401-3422$ (1988)) (limits access to an individual's financial records kept by financial institutions); the Fair Credit Reporting Act, Pub. L. No. 91-508, 84 Stat. 1128 (1974) (codified at 15 U.S.C. \$\$ 1681-1681t (1988)) (requires that consumer reporting agencies adopt procedures to ensure fairness and confidentiality); the Family Education and Privilege Act, Pub. L. 93-380, 88 Stat. 571 (1974) (codified at 20 U.S.C. $\$ 1232 \mathrm{~g}(1988)$ ) (describing conditions for inspection of educational records); and the Privacy Act, Pub. L. No. 96-440, 94 Stat. 1883 (1980) (codified at 42 U.S.C. $\$ \$ 2000 a a-2000 a a 12)$ (1988)) (defining scope of government's access to certain private materials in conducting a criminal investigation).

178. R. Hixson, supra note 18, at 219. These interests, while important, do not go to the heart of what the author perceives as the right of privacy. Although they are cognizable under the aegis of "privacy," they do not guarantec individual autonomy and choice in matters of fundamental importance.

179. Meyer v. Nebraska, 262 U.S. 390, 399-400 (1923); Pierce v. Society of Sisters, 268 U.S. 510 , 534-35 (1925). 
sumed the task of protecting privacy rights from the directly elected majoritarian governmental branches. Invoking the tradition of liberty reflected in the Bill of Rights and fourteenth amendment, the Supreine Court required that governinent justify its actions when challenged by those adversely affected by state laws.

1. The Use of the Tradition of Liberty in Early Privacy Case Law. In the 1920s, the Supreine Court used the liberty clause of the fourteenth amendment to vindicate privacy interests as a legitimate expectation of the citizenry. Meyer v. Nebraska ${ }^{180}$ and Pierce v. Society of Sisters ${ }^{181}$ established that parents have a privacy interest in raising tlieir children. Noting that the people of the United States believed that the education and upbringing of children was largely the responsibility of parents, the Court recognized and validated a community tradition of deference to parents in the rearing of their children. ${ }^{182}$ Thus, the Court looked to the tradition of community deference to parents raising their children ${ }^{183}$ rather than examining the traditional way in which children were

180. 262 U.S. 390,399 (1923). Meyer involved a challenge to a state statute which prohibited the teaching of foreign languages in private or parochial schools. Id. at 396-99. In finding the statute in violation of the fourteenth amendment's proteetion of "liberty" interests, the Court recognized that due process included the right to inake certain decisions of a personal nature. Id. The Court expressed this interest as a distinct claim of the citizenry against their state governments: "That the state may do much, go very far, indeed, in order to improve the quality of its citizens, physically, mentally and morally, is clear; but the individual has certain fundamental rights which must be respected." Id. at 401 .

181. 268 U.S. 510, 534-35 (1925). Pierce struck down a state statute requiring all children to attend public schools, as opposed to private or parochial schools. Id. at 530-32. Oregon's interest in ensuring the education of its children could not preelude the ability of parents, or families, to exercise choice with respect to the upbringing of children:

[W] think it entirely plain that the Act of 1922 unreasonably interferes with the liberty of parents and guardians to direct the upbringing and education of children under their control. ... The child is not the mere creature of the state; those who nurture him and direct his destiny have the right, coupled with the high duty, to recognize and prepare hun for additional obligations.

Id. at 535-36. Pierce, like Meyer, arises as a "liberty" interest case under the fourteenth amendment. Id. at 533. The Court recognizes that "liberty" encompasses autonomy with respect to a given matter not speeifically enunciated in the text of the Constitution. Id. at 535. This analytic framework paved the way for Griswold v. Conneeticut, 381 U.S. 479 (1965), which lield that implied rights exist within the broad language of the Constitution. See id. at 484. Pierce and Meyer help illustrate one of the quirks of U.S. privacy jurisprudence at the constitutional level: There is no express gnarantee of privacy in the document.

182. See Pierce, 286 U.S. at 534. The nse of tradition and community values in delimiting privacy/liberty interests has been rediscovered by the inodern Court. See, e.g., Bowers v. Hardwick, 478 U.S. 186, 191 (1986) ("[P]roscriptions against such conduct [homosexual sodoiny] have ancient roots."); Moore v. City of East Cleveland, 431 U.S. 494, 503 (1977) (The sanctity of family is proteeted by the Constitution "precisely because the institution of the family is decply rooted in this Nation's history and tradition.").

183. See Meyer, 262 U.S. at 399-400; Pierce, 268 U.S. at 535. 
raised. ${ }^{184}$ Drawing upon traditions of liberty enshrined in American society through the Constitution, the Suprene Court determined that an individual family's claim to be left alone trumped the state legislature's determination that the parents were raising their children inproperly. ${ }^{185}$ Meyer and Pierce accurately drew a line between the vindication of individual autonoiny and the regulation of beliavior by the community for the good of all.

2. Griswold: Privacy as a General Constitutional Right. Meyer and Pierce establislied a principle that exploded into new prominence in the 1960s. Building upon the intellectual foundation established by Meyer and Pierce, the Court greatly expanded the scope of the right of privacy. Toward this end, the Court cliaracterized privacy as a penumbra created by express textual provisions of the Bill of Rights and the fourteenth amendment. Alternatively, some inembers of the Court cast the notion of privacy as a particular kind of liberty interest, implicitly, if not explicitly, protected under tlie ninth or fourteenth amendinent. ${ }^{186}$

Griswold v. Connecticut, the landinark case of 1965, represented a inajor expansion of the constitutional protection of privacy. The case raised the question of whether a state could regulate the intimate details of the inarital relationship. ${ }^{187}$

Griswold involved a cliallenge to a ban by Comecticut on the use of contraceptive devices and the dissemmation of inforination or instruction on the use of such devices. ${ }^{188}$ Even thougli the statute had not been strictly enforced, ${ }^{189}$ it still stood as an impediment to effective family planning counseling and practice. Griswold, the Executive Director of the Planned Parentlood League of Connecticut, and a physician, provided counseling and instruction to inarried couples on various means of contraception. ${ }^{190}$ The Court struck down the Connecticut statute, finding that it unduly interfered with the inarital relationship. In deciding Griswold, the Court looked beyond the literal language of the Constitu-

184. See Meyer, 262 U.S. at 402; Pierce, 268 U.S. at 534.

185. Meyer, 262 U.S. at 402 ; Pierce, 268 U.S. at 535. Indeed, we know that insofar as the legislatures of Nebraska and Oregon had prohibited the parents' course of action, the relevant communities did not approve of how the parents were going about their parental duties.

186. Justice Douglas clearly accepted privacy as a free standing interest under the Constitution. See Griswold v. Conneeticut, 381 U.S. 479, 484-86 (1965) and his concurrence in Doe v. Bolton, 410 U.S. 179, 209-15 (1973) (Douglas, J., concurring). In contrast, some have argued that the Roe $v$. Wade Court could not, and did not, rely on privacy as a general constitutional right. See Ely, The Wages of Crying Wolf: A Comment on Roe v. Wade, 82 YALE L.J. 920, 931-33 (1973).

187. Griswold, 381 U.S. at 480-82.

188. Id. at 480 .

189. Id. at 506 (White, J., concurring).

190. Id. at 480 . 
tion's text to ensure that states did not arbitrarily infringe upon basic autonomy interests. ${ }^{191}$

Regardless of the precise source of the right of privacy, ${ }^{192}$ Griswold established that individuals could make claims of privilege against some state regulations. In Griswold, the promise of Meyer and Pierce caine to fruition with a full-fledged constitutional privacy doctrine. Although the right of privacy clearly does not always override state regulations, courts began to listen to arguments based on claims of autonoiny. ${ }^{193}$

191. By utilizing the ninth amendment to predicate a principle of deference toward individual autonomy, id. at 486-99, Justice Goldberg's concurring opinion resurrected the amendment in modem Constitutional law: "[T] fundamental rights exist that are not expressly enumerated in the first eight amendments and an intent that the list of rights included there not be deemed exhaustive." Id. at 492 . He noted that "the concept of liberty protects those persoual rights that are fundamental, and is not confined to the specific terms of the Bill of Rights. Id.

192. See The Slaughter-House Cases, 83 U.S. (16 Wall.) 36 (1873); H. PollacK \& A. SMrTH, Civil Liberties and Civil Rights In the United States 21-25 (1978); C. PritchetT, CoNSTITUTIONAL Civil Liberties 1-15 (1984).

The Slaughter House Cases held that the "privileges and immunities" language of the fourteenth amendment did not constitute a new limitation on the state governments' freedoin of action. The Slaughter House Cases, 83 U.S. at 78. The opinion, reviewed in light of the intervening 116 years, is more than a little iromic. The liberty clause of the fourteenth amendment was found to do what the textually more congemial "privileges and immumities" clause could not-incorporate the rights and liberties of the Bill of Rights. Palko v. Connecticut, 302 U.S. 319, 325 (1937) (only those rights enumerated in the Bill of Rights which "have been found to be implicit in the concept of ordered liberty, and thns, through the Fourteenth Amendment, become valid as against the states."); Twining v. New Jersey, 211 U.S. 78, 99-101 (1908) (Court considers possibility that due process clause might incorporate some of the Bill of Rights as against the states).

193. The Supreme Court continued to build upon the foundation enunciated in Griswold. Katz v. United States, a fourth amendment case, protected the expectation of privacy in electronic communications. 389 U.S. 347, 361 (1967). The case involved the tapping of public telepliones by the government in an interstate gambling investigation which led to criminal proseeutions. Katz was seemingly a clean victory for advocates of a right of privacy under the fourth amendment. However, Justice Stewart's majority opinion expressly deelined to adopt a general right of privacy. "[T]lie Fourtl amendinent cannot be translated into a general constitutional 'right to privacy.' " Id. at 350. This is not to say that the fourth amendment does not protect privacy interests. Rather, Justice Stewart believed that the fourth amendment is not limited to privacy interests, nor is it a proxy for a general right to privacy.

However, some meinbers of the Court perceived $\mathrm{Katz}$ as going too far in the direction of establishing a fourth amendment right of privacy. In the words of Jnstice Black, "the Court began referring incessantly to the Fourth Amendment not so much as a law agamst unreasonable searches and seizures as one to protect an individual's privacy." Id. at 373. Given the tenor of Justice Stewart's majority opinion, Justice Black's concern seems overstated. In Katz, Jnstice Black reacted against the increasing willingness displayed by the Court to recognize a general privacy right under the Constitution, related to, but distinct from, the strict textual provisions of the document. See id. at 374.

Katz was just one of several cases expanding and clarifying the privacy interests protected by individual amendinents. Stanley v. Georgia, 394 U.S. 557 (1969), used the first amendment to create a near-absolute right to privacy in the lome where free speech was inplicated. In the wake of Stanley, one has the right of privacy under the first amendment to peruse obscene materials in the home, but the state may prescribe the means of obtaining such material commercially. Id. at 567 . 


\section{B. Autonomy Rights Are Correctly Vindicated Through the Modern Right of Privacy}

The development of the right of privacy in constitutional adjudication reflects the Court's frank recognition that the Constitution guarantees individuals protection from undue governmental regulation of private life, despite the commumity's concern for its own security and well-being. Yet the Court realized that some hiberty interests are too destructive to the commumity's existence to be countenanced. Thus, in the privacy cases, ${ }^{194}$ the Court utilized the tradition of liberty in the United States im order to limit the riglit of privacy and affirm the commumity's right to regulate for the good of all its inembers.

In the abortion cases, ${ }^{195}$ the Court apphied the test of community deference to individual liberty suggested by Meyer and Pierce. These cases reflect a balancing of interests: the individual's right to make reproductive clioices verses the community's interest in the protection of potential life. However, the Court may be slifting away from Meyer, Pierce, and Griswold. The most recent privacy cases reflect a disturbing trend toward the vindication of majoritarian inoral choices, rather than the tradition of hiberty set forth in Meyer and Pierce. In cases involving sodomy and parental rights, the Court has utilized a new and potentially dangerous test-tlie tradition of community approval of a particular lifestyle. ${ }^{196}$ This new test reflects an infusion of majoritarian clioicemakmg into what should be an analysis of the scope of individual autonoiny.

1. The Abortion Decision's Test: Community Traditions of Autonomy in Moral Decisionmaking. Roe v. Wade, the controversial decision that granted women a constitutional riglit to abortion, reaffirmed the constitutional right of privacy established in Griswold. ${ }^{197}$ Roe also set forth a balancing test to resolve conflicts between individual privacy and legitimate state interests. ${ }^{198}$ The Court held that only a "coinpelling

The right of privacy enunciated in Stanley applies only in the home itself. In United States v. Reidel, 402 U.S. 351 (1971), the Court held that Stanley did not extend to the right to use the mails to obtain obscene materials. Id. at 355-56 ("To extrapolate from Stanley's right to liave and peruse obscene material in the privacy of his own home a First Amendment right in Reidel to sell it to lim [Stanley] would effectively scuttle Roth [v. Umited States, 354 U.S. 476 (1957)], . . . and we decline to do so now.").

194. See, e.g., Griswold v. Connecticut, 381 U.S. 479 (1965); Roe v. Wade, 410 U.S. 113 (1973).

195. Webster v. Reproductive Health Servs., 109 S. Ct. 3040 (1989); Carey v. Population Servs. Int'l, 431 U.S. 678 (1977); Planned Parenthood of Central Missouri v. Danforth, 428 U.S. 52 (1976); Roe v. Wade, 410 U.S. 113 (1973).

196. See infra notes $206-21$ and accompanying text.

197. 410 U.S. 113, 152-54 (1973).

198. See id. at 154. The balancing test enunciated in Roe, and used in later abortion cases, slows that even where fundamental rights are implicated, the state may prevail in delimiting behav- 
state interest" could justify an invasion of the "right of privacy."199 Although the Court referred to other constitutional amendments to support its holdmg, ${ }^{200}$ the majority secured the privacy interest from state intervention primarily through the fourteenth amendment's liberty provision in connection with the ninth amendment privacy interest. ${ }^{201}$

Thus, a majority of the Court finally accepted a specific formulation of a general right of privacy. Roe coinpleted the process that began in the 1920s with Meyer and Pierce. The federal Constitution created limits upon both the federal and state governments; governmental power was cabined by the vesting of residual power in the individual citizens. According to the Court, invasive state regulations could not unduly burden legitimate autonomy interests.

Roe's approach to privacy survives today. Although Webster v. Reproductive Health Services directly challenged the Roe decision, it did not repudiate the privacy interest recognized in Roe. ${ }^{202}$ Webster involved a Missouri law seemingly imconsistent with the Supreme Court's opimion in Roe. ${ }^{203}$ Although the Supreme Court sustained several key portions of the law, 204 the Court expressly declined to overrule Roe. ${ }^{205}$ Therefore, Webster leaves intact the fundamental interest/coinpelling state interest balancing test for analyzing privacy claims, but recognizes a greater state interest in the fetus than the Court accorded in Roe.

Abortion provides an example of the dilemma introduced by "undesirable" conduct that arguably falls within the domam of individual liberty. Abortion generally is not seen as a desirable experience, but rather as an unfortunate event to be avoided. When a court inquires as to whetler the state should regulate abortion the outcome often hinges on the manner in which the court poses the question. If the court asks, "Does the community advocate abortion as a valuable activity?", it will arrive at negative response. In contrast, if the Court asks whether the

ior if its "compelling interest" is sufficiently weighty. See Webster v. Reproductive Health Servs., $109 \mathrm{~S}$. Ct. 3040, 3054-57 (1989). Privacy is not the enunciation of an absolute interest, but rather of a cognizable interest which must be considered before the state intrudes into individual autonomy. Bowers v. Hardwick, 478 U.S. 186 (1986), makes plain that some interests potentially protected under the right of privacy fall prey to state intrusion.

199. Roe, 410 U.S. at 155.

200. See id. at 152 (referring to the first, fourth and fifth amendments and the "penumbras of the Bills of Rights").

201. Id. at 153 .

202. 109 S. Ct. 3040, 3058 (1989) (court says existence of the abortion right not at issue and that Roe is "undisturbed").

203. Webster, $109 \mathrm{~S}$. Ct. at $3047-48$.

204. Id. at 3052-53. The Court upheld Missouri's decision not to commit any public funding to abortion-whether through direct subsidy or indirectly through the use of state subsidized facilities or services-by recognizing that the district court should not have passed on an issue that was inoot. 205. Id. at 3058. 
community approves of the state encroaching upon individual privacy by limiting access to abortion, a different answer is both possible and likely. If one acknowledges that the Umited States people-and their Constitution-adhere to a basic tradition of individual liberty, then the court must choose the second formulation of the question. Of course, asking the second question does not mean that an individual's privacy clain will prevail-it merely requires the state to justify its intrusion into the individual's private life.

2. The Competing Test: Requiring Community Sanction for a Given Activity. Contrary to the early trend to protect individual choice in sexual and reproductive matters, ${ }^{206}$ the court in Bowers v. Hardwick lield that the right of privacy under the hiberty clause of the fourteenth amendment did not protect individuals who wished to engage in private homosexual sodomy. ${ }^{207}$ The Court seened to require that the activity in question have commumity sanction before it would be accorded protection as a privacy interest. The Court noted that because " 24 states and the District of Columbia" had laws prohibiting sodomy, sucli conduct could not meet the test of being "deeply rooted in this Nation's history and tradition."208 This test suggests that an individual must legitimate a claim of privacy by demonstrating the commuinty's acceptance of a particular behavior, ratlier than demonstrating the community's tolerance of individual choice in the area. ${ }^{209}$ When courts vindicate liberty interests, neither the commumity nor the court necessarily sanctions a particular behavior. Rather, decisions recognizing an individual's right of privacy merely demonstrate the commumity's willingness to allow individuals to make their own moral decisions.

A more recent case, Michael H. v. Gerald $D .{ }^{210}$ further illustrates this trend. In Michael $H$., a natural fatler established a relationship witl his adulterously conceived child. The biological mother and her husband subsequently sought exclusive parental rights to the child ${ }^{211}$-an outcome permitted by California law which conclusively presuined that children born to a married couple were the offspring of the couple.212 The plurality opinion of the Court, written by Justice Scalia, found that

206. Specifically, Meyer, Pierce, Griswold, Roe, and Webster. See supra notes 180.86 and accompanying text.

207. 478 U.S. 186, 190-91 (1986).

208. Id. at 193-94.

209. Interestingly, Justice Powell, in concurring with the opinion, noted that the Georgia law had not been enforced "for several decades." Id. at 198 n.2. If this was so, one might ask whether the community tradition was accurately reflected in the statute.

210. 491 U.S. 110 (1989).

211. Id. at 113-17.

212. Id. at $117-19$. 
Michael $\mathbf{H}$. had no constitutionally protected privacy interest in his relationship with the child. ${ }^{213}$ Justice Scalia admonished that "[o]ur cases reflect "continual insistence upon respect for the teachings of history [and] sohid recognition of the basic values that underlie our society." "214 He later noted that "our traditions liave protected the marital family." 215 The Court, finding no accepted liberty interest, did not even engage in the fundamental interest/compelling state interest balancing. Justice Scalia explained: "In an attempt to limit and gnide interpretation of the [due process] Clause, we have insisted not merely that the interest denominated as a 'liberty' be 'fundamental' . . . but also that it be an interest traditionally protected by our society" 216 Justice Scalia argued that tradition always lias favored the nuclear marital family and that "adulterous fathers" have never had protected parental riglits.

In footnote 6 of his plurality opinion, Justice Scalia opined that "[w]e refer to the most specific level at which a relevant tradition protecting, or denying protection to, the asserted right can be identified."217 This formulation of the question ensures that the community's moral preferences, rather than a tradition of deference to individual decisionmaking, will control the adjudication of privacy claims. ${ }^{218}$ From the standpoint of the protection of privacy, a better way to use tradition in Michael $H$. would have been to ask wlietlier tlie community has recognized the interest of botls the natural parent and the child in maintaining a mutual relationship-regardless of whetler the parental relationship is coextensive witlı a marital relationship. This approacl emphasizes liberty, but not at the expense of community values. ${ }^{219}$ The difference between asking the individual liberty question and the Court's approacls in Michael $H$. appears in the zone of protected autonomy that emerges from the answer. In Michael $H$., tlie Court extended toleration only as far as contemporary morals sanction a particular beliavior. Such liberty is no

213. Id. at 130 .

214. Id. at 122-23.

215. Id. at 124 (quoting Griswold v. Connecticut, 381 U.S. 479, 501 (1965)).

216. Id. at 122 .

217. Id. at 127-28 n.6.

218. A tradition of liberty can always be broken down into discrete acts, any number of which the cominunity niay disapprove. The question then becoines whether broader traditions should always be ignored in favor of narrower traditions related to a discrete type of behavior.

219. I do not niean to suggest that the result in Michael $H$. would be different under the alternative analysis I suggest. Michael $H$. is a difficult case, even if one broadly applies community traditions of liberty. 
liberty-it is merely the freedom to conform. ${ }^{220}$ Freedom entails the right to make bad clioices as well as good choices..221

As the Supreme Court's most recent pronouncement on privacy, Michael $H$. appears to represent a reshaping of the riglit. In particular, footnote 6 of the plurality opinion seems to depart from earher privacy decisions. ${ }^{222}$ Justice Scalia's requirement that the inost specific level of a relevant tradition control the privacy analysis does not square witl the holdings of Meyer and Pierce. The most specific level at which a tradition could be identified in Meyer and Pierce would have been the particular type of instruction at issue. History is replete with examples of state regulation of school curricula and mandatory attendance at accredited institutions. ${ }^{223}$ In Meyer and Pierce, the Court looked to a broader tradition-to the tradition of deference to parents im raising their children. Thus Michael $H$. (and particularly footnote 6) represents a marked departure from the Court's earher approach to privacy rights. ${ }^{224}$ Indeed, Michael $H$. attempts to complete the shift away from Meyer, Pierce, and Griswold that began with Bowers. 225

3. The Correct Use of Tradition Is Essential to Vindicating Legitimate Autonomy Interests. Bowers and Michael H. demonstrate the importance of asking the relevant question if the Court wishes to use

220. See Michael H., 491 U.S. at 141 (Brennan, J., dissenting) (fourteenth amendment and the nature of our society require toleration of "someone else's unfamiliar or even repellant practice because the same tolerant impulse protects our own idiosyncracies").

221. The autonomy/individual choice approach to tradition in validating privacy claims would not be a meaningless test. Some activities are seen as so destructive, and so damaging to the community's sense of well being as to not allow any room for individual autonomy-consensual human sacrifice or the use of illicit drugs provide good examples.

222. Michael H., 491 U.S. at $127-28$ n.6 (1989).

223. More specifically, Nebraska, the setting for Meyer, had a community tradition of diseouraging the teaching of German, while Oregon, where Pierce arose, had a tradition of requiring all minor children to attend secular public schools.

224. Michael H., 491 U.S. at 132 (O'Connor, J., concurring) (refused to adopt the single mode of historical analysis outlined in footnote 6 , and noted its inconsistency with some Supreme Court precedents protecting rights at levels of generality above the "most specific level" available).

225. See supra notes 208-19 and accompanying text. In Bowers v. Hardwick, 478 U.S. 186 (1986), the majority phrased the question as follows:

The issue presented is whether the Federal Constitution confers a fundamental right upon homosexuals to engage in sodomy and hence invalidates the laws of the many States that still make such conduct illegal and have done so for a very long time.

Id. at 190. Justice Blackmun would have none of it. Dissenting, lie pointed out that:

This case is no more about "a fundamental right to engage in homosexual sodomy," as the Court purports to declare, than Stanley v. Georgia was about a fundamental right to watch obscene movies, or Katz v. United States was about a fundamental right to place interstate bets from a teleplone booth. Rather, this case is about "the inost comprehensive of rights and the right most valued by Civilized men," namely, "the riglit to be let alone." (citations oinitted).

Id. at 199 (Blackmun, J., dissenting). 
community values as a touchstone for protecting liberty interests. Bowers asked whether the community historically approved of behavior "X." A different question is whether the community traditionally has classed "X" as a decision left to the individual. The Court in Meyer and Pierce used this second question to develop a balancing test.

In the case of homosexual sodoiny, Americans generally do not advocate either the act or the lifestyle of those who engage in it.226 But the answer to the question of whether most Americans would want the state to regulate sexual behavior in the bedrooms of America is far more ambiguous. $^{227}$ The historic lack of enforceinent of the sodoiny statutes suggests that the states have higher priorities than elimmating sodo1ny. ${ }^{228}$ Yet the existence of laws criminalizing sodoniy must in some way reflect community sentiments. The community may beheve that without an officially stated disapprobation of an undesirable behavior, the behavior may beconie commonplace. ${ }^{229}$ Hence, the statement of disapproval operates to create a tendency toward the community's idea of virtue. The prohibition is not intended to coerce virtue: Some laws are meant to be positive commands bindinig upon all, whereas some are niere precatory statements of a community's moral norms.

226. The hesitance to repeal state sodomy laws, and the negative stereotypes of homosexuals in the United States, suggest that the community does not approve of, much less advocate, sodomy. See Survey on the Constitutional Right to Privacy in the Context of Homosexual Activity, $40 \mathrm{U}$. Miami L. Rev. 521, 523-28 (1986); R. Bork, The Tempting of AMERICA: The Political SEDUCTION OF THE LAW 249-50 (1990).

227. For example, the New York Court of Appeals struck down New York's criminal sodomy statute in Pcople v. Onofre, 51 N.Y.2d 476, 415 N.E.2d 936, 434 N.Y.S. 947 (1980). The court noted the privacy interest manifested as individual decision making:

At the outset it should be noted that the right addressed in the present context is not, as a literal reading of the phrase might suggest, the right to maintain secrecy with respect to one's affairs or personal behavior; rather, it is a right of independence in making certain kinds of important decisions, with a concomitant right to conduct oneself in accordance with those decisions, undeterred by governmental restraint-what we referred to . . " as freedom of conduct."

Id. at 485,415 N.E.2d at 939,434 N.Y.S. at 949 . Interestingly, the Court made liberal reference to Brandeis' dissent in Olmstead. Id. at 485-88, 415 N.E.2d at 939-40, 434 N.Y.S. at 949-51. The decision could be read as resting on tradition, to the extent that personal autonomy and liberty are part of the American tradition. Id. at 485-91, 415 N.E.2d at 939-42, 434 N.Y.S.2d 949-53. The Court also concludes that behavior that does not injure anyone else should be unregulated. Id. at 490,415 N.E.2d at $941-42,434$ N.Y.S.2d at 952.

228. In Poe v. Ullman, the Supreme Court refused to reach the merits on a challenge to Connecticut's ban on the distribution, sale, or provision of birth control because the law had fallen into desuetude. 367 U.S. 497, 507 (1961) ("During the more than three-quarters of a century since its enactment, a prosecution for its violation seems never to have been initiated."). Poe illustrates how the existence of a criminal statute does not establish that a community is resolved to prohibit a particular act.

229. The maxim that "hypocrisy is the tribute life owes to virtue" is apropos. 
A law may or may not reflect community tradition regarding a particular matter. ${ }^{230}$ Some legal thinkers suggest that legislative inaction reflects the contimuing approbation of the community in regulating private behavior. ${ }^{231}$ Yet, for a variety of reasons, such as a desire to avoid the taint of any association with a controversial question, a legislature may fail to repeal precatory laws even though this failure to act causes a result that does not represent general community thought on a given matter. ${ }^{232}$ Courts can and should look to the existence of laws prohibiting conduct in their attempt to divine tradition. However, even if a law prohibitimg a certain course of action exists, the courts niust also look to whether the history of the enforcement of the law confirms its use as the dispositive source of the commumity's traditions.

Tradition can legitimize privacy claims-essentially clainis of autonomy-agamst the community, even if the community disapproves of the protected behavior. Because the right of privacy lacks a clear constitutional mandate, ${ }^{233}$ the use of a tradition of individual liberty as a legitimating touchstone is a desirable, persuasive, and perhaps, necessary approach. There is a danger, however, that the Court will ask the wrong question when it seeks to delineate the contours of the American coinniumity's "tradition" on a given matter. ${ }^{234}$ Thus, how the Court asks the question prefigures the ultimate resolution.

230. For instance, many states prohibit all forms of gambling on sports events. Nevertheless, small wagers on collegiate and professional athletics have been, and remain, a strongly enshrined American tradition. USA Today does not publish odds on such events soley for the edification of game theorists.

231. R. BORK, supra note 226 , at $248-50,352-53$.

232. American legislatures are highly sensitive as to how their actions are perceived. Historically, they are not eager to take positions opposed by vocal minorities, even when the general population holds an opimion that is contrary to that of the minority group. See generally P. ATIYAH AND R. SUMMERS, supra note 20, at 314 ("The passage of bills in a state legislature often says very little about the 'will' of the legislature, and still less about the will of the electorate.").

233. Nowhere in the Constitution is "privacy" expressly mentioned. Professor John Hart Ely clearly beheved that Roe could not be justified on legal principles, since it lacked a firm constitutional touchstone: "At times the inferences the Court has drawn from the values the Constitution marks for special protection have been controversial, even shaky, but never before has its sense of an obligation to draw one been so obviously lacking." Ely, supra note 186, at 936-37. Ely is not unsympathetic to the result in Roe, but believes that the Court lacked tlie competence to interfere with the states' legislative pronouncements on this matter without providing a sounder foundation. Id. at 926-27, 931-33.

234. Anotler muportant consideration is what the relevant "community" should be for constitutional privacy analysis. The tentlı amendment possibly suggests a state-by-state analysis of tradition to determine whether the relevant state had a listory of deference to clioice on a given matter. However, this would result in 51 different privacy precedents, each to be protected by the federal judiciary, a clearly untenable position. But cf. Miller v. California, 413 U.S. 15, 24 (1973) (Court allows "contemporary community standards" to control obscenity trials; the Court apparently views localities and/or states as permissible governmental units from whicl to define obscenity). Miller imvolved the exclusion of materials from first amendment protection. However, in Reynolds $v$. 
A separate but related problem arises because of the changing nature of tradition. By definition, tradition is determined by reference to the prior practices of the relevant community group. Conceivably, the use of the tradition of liberty as an exclusive test might result in shifting privacy rights that would undermine the persuasiveness of precedent and that would erode the legal force of court decisions. This problem is easily surmounted: Privacy riglits should move in only one direction-toward greater levels of protection. Thus, over timie, the court should "ratchet up" the number of liberty interests recognized, but should not "ratchet down" the sphere of protected personal autononiy, even if the conteinporary community's values are shifting. The application of the ratchet approach requires a reviewing court to resolve two issues: is the mterest claimed one of the class already recognized, and if not, slould it be recognized as a legitimate autonomy claim. If the Court determines that conduct falls within a tradition of community deference to individual liberty, then it will strike down attenipts at reregulation, thus precluding a future change in tradition, absent constitutional amendment. Alternatively, the Court should examine traditions of community deference as a primary test for validating yet unrecoginzed claims of privacy. If such a tradition is not present-as is the case with illicit drugs-the Court would then consider whether the beliavior was so fundamentally armexed to notions of "liberty" that it commands constitutional protection under the language of the fourteenth amendinent. ${ }^{235}$ In applying the second step, the court should look to whether the states have traditionally regulated the conduct and also to whether sucl regulations have been consistently enforced. The use of this two step process would resolve the problenis inherent in the use of tradition as a constitutional test.

The court's renewed use of tradition as a means of determining privacy claims could be a welcome developnient. Since the first privacy cases, American privacy law lias lacked both procedural regularity and substantive consistency. Tradition offers a rational means of cabining the scope of the right; procedural regularity (predictable application of clearly articulated tests) is a nuatter of self-discipline on the part of the

United States, 98 U.S. 145 (1879), the Court refused to respect a local tradition in the Utah territory-bigamy. If Meyer and Pierce were correctly decided, the Court must look to a national-not local-tradition in setting the minimal parameters of "liberty." The relevant "community" must be national in scope, at least insofar as is needed to secure the minimal protection of liberty interests. The notion of "liberty" in the fourteenth amendment logically cannot be a state-specific concept.

235. Essentially, this is the how the test works under current precedents. A citizen may attempt to raise a privacy claim by showing that the interest has the imprimatur of "tradition," or by showing that the interest is "imphicit in the concept of ordered liberty." The former test is the approach used in Moore v. City of East Cleveland, 431 U.S. 494, 503-06 (1977), and the latter one of Palko v. Connecticut, 302 U.S. 319, 325 (1937). 
courts. The neasure of liberty afforded United States citizens by the right of privacy is and reniains a function of both substance and process.

\section{Privacy: Individual Autonomy v. CoMmunity Self-Regulation}

The British judiciary refuses to recognize a general right of privacy, either under domestic law or under article 8 of the ECHR.236 Conversely, American courts view privacy rights as fundamental and justiciable interests. Both nations have histories that emphasize individual right and hiberty. The apparent difference in means (if not ends) can be explained by realizing that the British and American courts have developed into functionally different institutions. ${ }^{237}$ Neither of these institutions, however, adequately and predictably vindicate the autonomy interests of their citizens. In Britain, minority groups are denied a doniestic forum in which to challenge laws that unduly interfere with their private hives. In the United States, citizens who claim the right of privacy have little certainty with regard to the scope of the right or the standards a court will use to evaluate their claim.

\section{A. A Right of Privacy Is Necessary in the United States' Legal System}

The use of tradition as a constitutional touchstone transformus the individual claim of a right of privacy into a liberty niterest bestowed on the individual by the comınunity. Viewed in this way, the right of privacy is not a "right to be ungoverned," but rather a right to be partially "self-governing" in matters related to the core of who we are and what we aspire to be and do.

Sonie British comnientators view American privacy law as an anarchistic passion to be ungoverned somehow not yet bred out of the nation. ${ }^{238}$ This British view may be partially correct. A privacy right rests upon an individualistic concept of society, sometimes manifested in the unfortunate extreme "each man for himself, and the devil take the hindmost." 239 The United States tradition eniphasizes the benefits of selfgovernment-the right and the responsibility of the nidividual to think for himself in order to determine the best life course. Our society recognizes that behief im a summum bonum, a best life, does not mean that any one person or group of persons has been blessed with perfect knowledge of it. The free exercise of reason, coupled with the trial and error process

236. See supra notes $21-34,172-73$ and accompanying text.

237. See P. Atryah \& R. Summers, supra note 20 , at $35-41$.

238. YOUNGER REPORT, supra note 15 , at 19.

239. R. Hixson, supra note 18 , at $\mathrm{xv.}$ 
of experience, nray be the only way for the individual and the community to work toward happiness. ${ }^{240}$ Privacy rights play a key role in this process because they protect the process of self-definition. Self-definition through the exercise of personal autonoiny is a gradual process. In makmg moral choices and in hiving with the consequences, reason and experience move the individual toward greater self-knowledge and understanding. ${ }^{241}$

Recognizing the utility of privacy as an end does not provide a means for securing personal autonony. For privacy rights to be effective, their scope and application must allow individuals to recognize the activities that are within the aegis of the right. Predictability is lost when the parameters of a right are ill-defined.

Although privacy adjudication presently lacks needed predictability, there are several avenues by which the scope of the privacy right can be delineated. Justice Scalia's approach seeks to define privacy by arbitrarily limiting the scope of the privacy right. ${ }^{242}$ Conversely, the British protect some privacy interests, but only on an ad hoc basis. Both of these approaches have their failings. A piecemeal approach to the vindication of privacy interests is insufficient because nany issues will remaim unresolved. ${ }^{243}$ Arbitrarily limiting the objects of a broadly crafted privacy right seriously undervalues the benefits of personal autonomy, ceding residual power not with the people, but with the government. There is an alternative to choosing between either a narrow but specific right of privacy or a vague but inclusive privacy right. A return to the American tradition of hiberty, evidenced in Meyer, ${ }^{244}$ Pierce, ${ }^{245}$ and Moore v. City of

240. For an example of this kind of natural law reasoning, the writings of Thomas Jefferson are illustrative:

Man was destined for society. His morality therefore was to be formed to this object. He was endowed with a sense of right and wrong merely relative to this.... [The moral sense] may be strengthened by exercise, as may any limb of the body. . . . Fix reason firmly in her seat, and call to her tribunal every fact, every opinion.

Letter from Thoinas Jefferson to Peter Carr (Aug. 10, 1787), reprinted in The PoRTable Thomas JefFERSON 423, 424-25 (M. Peterson ed. 1985).

241. "The unexamined life is no life for a human being." Plato, Apology, in 1 Dialogues of Plato *38a (B. Jowett Trans. 1953). An Enlighteninent notion of pre-social rights secms to survive in the United States. See R. Hixson, supra note 18, at 97-102. Americans beheve that they have a right to retain interests as against both the government and the community. The attitude of Americans toward their legislatures exemplifies this behief. Americans do not want the government to become a sort of collective parens patriae. See P. ATIYAH \& R. SUMMERS, supra note 20, at 270-71; see also 311-15.

242. This is precisely what Justice Scalia attempts to do in his opinion in Michael H. v. Gerald D., 491 U.S. 110, 127-28 n.6 (1989).

243. Ironically, although not specifically mentioming the United States, the British point out this defect in the YOUNGER REPORT, supra note 15, at 197-98.

244. 262 U.S. 390 (1923).

245. 268 U.S. 510 (1925). 
East Cleveland, ${ }^{246}$ but not in Bowers ${ }^{247}$ or Michael H., 248 could provide the necessary framework through which to vindicate privacy rights consistently and predictably. ${ }^{249}$ The relevant tradition derives from the Enhightenment tradition that imbued the founding of the Republic-a tradition of intellectual independence and personal autonomy, rather than one of direct government supervision of the minutiae of one's private life.

Because notions of privacy are related to notions of autonomy, a legally cognizable privacy interest agamst the government is unexceptional. Americans' predisposition to rely on rights against the government may also be explained, in part, by the pluralistic nature of the populace. A nation of immigrants, the Uinted States welcoined settlers froin different nations, races, and rehigions. As a result, legislatures can be mistrusted, particularly by minorities who feel either unrepresented or underrepresented by a particular body. ${ }^{250}$ Minority interests rely on the courts to vindicate the inajoritarian promises of liberty, endangered by majoritarian legislation. A sinall minority probably cannot convince a legislature to protect its interests. Thus minorities view the counterinajoritarian courts, which at the federal level do not specifically answer to any interest group, as the best potential means of securing relief.

I advocate a privacy law that focuses on tradition, but also on substantial rehance on strict observation of process. ${ }^{251}$ The right of privacy represents a coruucopia of distinct interests, organized under the rubric of "privacy."252 Whether a particular interest is or is not accorded protected status is not as important as the existence of the privacy right itself. Ultimately the point is not that " $\mathrm{X}$ " is or is not a privacy right, but rather that the American courts are prepared to examine the question on its inerits. ${ }^{253}$ From this perspective Roe's process approach best

246. 431 U.S. 494 (1977).

247. 478 U.S. 186 (1986).

248. 491 U.S. 110 (1989).

249. I am not suggesting that tradition be used as a means of imposing a narrow set of values. Rather, if tradition is used to define areas where the community has in practice deferred to individual choice, it may provide a useful limiting principle. To the extent that "tradition" is used to impose a "motherhood and apple pie" morality directly upon the population through the evisceration of "liberty" interests, the effect is unwarranted and pernicious.

250. P. ATIYAH \& R. SUMmers, supra note 20 , at $312-15$.

251. See supra notes 224-34 and accompanying text.

252. See, e.g., Roe v. Wade, 410 U.S. 113, 152 (1973) (a survey of various rights of privacy found by the Suprene Court under various constitutional amendments). This is also exemplified in Griswold v. Connecticut, 381 U.S. 479 (1965) where the court attenipts (without success) to spell out the contours of a defined and limited interest. See also A. Westin, Privacy AND Frezdom 350, 359. 60, 365-69 (1967).

253. Webster is a good example. The Court entertained the privacy claim, but after applying the balancing test enunciated in Roe came down on the side of the state interest, at least with respect to 
vindicates legitimate privacy claims while Michael $H$. ignores the citizen's right to force government to justify its acts.

The problem of predictability remains. The Griswold line of cases failed to specify with any cogency how or when the compelling state interest balancing test is to be applied. Although the concept of "liberty" certainly suggests some sphere of autonomy, courts struggle to identify "fundainental interests" and to balance them against the "compelling state interests."254 Thus the United States has failed to draw clear lines so that citizens nay live their daily lives secure in the knowledge that their acts are legal.

The renewed use of tradition by the Supreme Court to validate privacy interests could potentially help delimit the right of privacy. ${ }^{255}$ If the federal courts would consistently apply the two step approach advocated by this Note, ${ }^{256}$ then the problem of predictability would be substantially resolved. The fundamental problen lies in the determination of the relationship between individual autonomy and self-definition on the one hand, and the community's perceived need to control individuals to protect itself and its sense of well-being on the otler. Nevertheless, the federal courts can and should surmount this difficulty.

\section{B. Britain Also Needs a Right of Privacy}

Britain should adopt a right of privacy in its domestic law. If Parliament will not act, then the courts should assert themselves nore forcefully through the common law. ${ }^{257}$ There are two reasons for this conclusion. First, large areas of personal autonomy are hostage to parlia-

the particular Missouri statutes in question. Webster v. Reproductive Health Servs., 109 S. Ct. 3040, 3056-58 (1989). One must bear two things in mind in the wake of Webster: First, the privacy balancing test has survived the Reagan Court, and is an accepted doctrine of American jurisprudence, and second, that whether a particular action or forbearance is cognizable as a privacy right is not always an easy question for the present court. See supra notes 208-34 and accompanying text.

254. See People v. Onofre, 51 N.Y.2d 476, 485, 415 N.E.2d 936, 939, 434 N.Y.S.2d 947, 949 (1976) (privacy is "a right to independence in making certain kinds of important decisions").

255. R. WACKS, supra note 2, at 10-23; YOUNGER REPORT, supra note 15, at 19. See supra notes 206-32 and accoinpanying text for a discussion of the potential dangers in using tradition as the source of privacy rights.

256. See supra notes $230-35$ and accompanying text.

257. The easiest way for the courts to accomplish this task would be to create a common law right that parallels article 8 . The British judiciary could not unilaterally incorporate article 8 per se consistently with the present state of British constitutional law. See supra note 122; Dworkin, Privacy and the Law, in PrIVACY, supra note 14, at 133. For example, Lord Denning has said, "It [article 8] is so wide as to be incapable of practical apphicatiou." R. v. Chief Immigration Officer, Heathrow Airport, ex parte Bibi, [1976] 1 W.L.R. 979, 984; see also R. WACks, supra note 2, at 178 (only benefit of article 8 is its "catalytic effect on our legislators in the event of an adverse ruling by the European court").

Another consideration is the general contempt which the domestic courts of Great Britain have for the European Court, which gives "mere opinions" rather than holdings predicated on law. See 
mentary fiat under the present state of the law. Second, Britain has an international obligation under the ECHR to vimdicate a right of privacy pursuant to article 8.258 Yet, for many reasons, it is unlikely that Britain will adopt a riglit of privacy in the immediate future.

Rights exist only if the relevant decisionmakers affirmatively decide to confer a power of decision back to the community. For a right of autonomy to exist, the community must adopt it througl Parliament. One of the principal problems is the British legal system's emphasis on predictability, stability, and the maintenance of the distinction between the law as it is from the law as it ouglit to be.259 If Parhament is fairly elected and entirely representative, then individual claims to be privileged from governance are selfisli, if not absurd.

However, the British Parhament may decide questions of policy free from constitutional constraints. ${ }^{260}$ Positivism - the idea that the law must be apphied as it is-leads courts to apply the law before them witl1out questioning the purposes that the law is meant to serve. For better or worse, positivism is one of the theoretical bulwarks for the supremacy of Parliament. ${ }^{261}$ Positivists attempt to separate law and morality at the time laws are applied. Thus, Parhiament may consider etliical matters when passing a law, but this is the only time when morality should enter into the consideration of legal consequences. Legal positivists generally are uureceptive to the idea that an act of Parliament, passed properly and clear in all of its provisions, slould be unenforced by the courts because it offends some individual's right of privacy - a right unexpressed at law, and self-evident in nature. ${ }^{262}$

Although divorcing law from morality at the time courts actually apply laws is one way to approach privacy questions, this approach ultimately may be more problematic than the American substantive approach to privacy law. ${ }^{263}$ It requires something of a leap of faitli, if one

P. ATIYAH \& R. SUMmers, supra note 20 , at 423 . As such, they are theoretically not entitled to any more deference from the courts than are anyone else's opinion.

258. "It is worth emphasising [sic] that the E.C.H.R. envisages recourse to its Commission and Court as a last resort for aggrieved imdividuals." Dowrick, supra note 25, at 887-88. Of course, the ECHR machinery is the first resort for British citizens arguing article 8 or any other substantive right not having an analogue in domestic British law.

259. P. ATIYAH \& R. SUmmers, supra note 20, at 148-50; see also H. Kelsen, General TheORY OF LAW AND STATE 120 (1945) (discussing generally the tension between the "ought" and the "is" in legal order).

260. P. ATIYAH \& R. SUMmers, supra note 20, at 227, 257-63, 266 (developing the historical relationship between the British constitutional framework, including Parhiamentary supremacy, and legal positivism).

261. Id. at 3 .

262. Id. at 224; R. Hrxson, supra note 18, at 93-104.

263. Comment, Abortion and Statutory Interpretation, LAw \& JusTiCe, Spring 1982, at 2, 3. 
lives in a pluralistic society (which Britain is rapidly becoming), to presume Parliament correctly resolves all issues when legislating.

A right of privacy in Britain will coine, if at all, from one of the international conventions. ${ }^{264}$ Britain could adopt a riglit of privacy either through a Parliamentary Act that domestically recognizes the ECHR or through the aggressive use of the principles enunciated in ECHR by the EEC. A narrowly defined parliamentary adoption of a right of privacy, particularly as agamst the government, would not cause irreparable harm to the British constitutional framework and would benefit substantially the growing minorities within Britain.

Parhament has, of course, specifically recognized some privacy interests through limited statutory enactments. In repealing the "sinlaws," Parhament has apphed a kind of "compelling state interest" test, witlout expressly recognizing an individual privacy riglit. For example, in the Wolfenden Report on Homosexuality, the Committee approached the question of government regulation not in terms of privacy or individual right, but rather in terms of whether consensual sexual behavior was any concern of the state. ${ }^{265}$ However, this built-in legislative restramt does not always succeed in protecting arguable privacy rights-especially when state security or law enforcement is at stake. ${ }^{266}$

264. As a result of positivist legal philosophy, "[s]tatutes in the United Kingdoin require greater specificity to compensate for the limited judicial role." W. PRATT, supra note 23, at 207. A statute that purported to create a general right of privacy would be an anomaly in the British systen of government. Traditional institutional roles also work against the creation of a right of privacy. The present judiciary lias neither the disposition nor the administrative resources to police a broad right of privacy. See P. ATIYAH \& R. SUMMERS, supra note 20, at 279-83; W. PRATT, supra note 23, at 206-07. In the United States, judges generally have a battery of clerks and secretaries, in addition to hbraries and docket clerks. Further, the increasing use of nagistrates and staff attorneys suggests that chambers in the United States are becoming mini-bureaucracies. P. ATIYAH \& R. SUMMERS, supra note 20, at 281-82. In contrast, judges in Great Britain lack the clerks, secretaries, and libraries needed to assume a quasi-legislative function. Id. at 279-81.

265. W. PRATt, supra note 23, at 126 n.105, 131; REPORT OF THE COMMTTTEE ON HOMOSEXUal OFFenCes aNd Prostitution, 1957, CMnD. No. 247 [heremafter Wolfenden Committec].

266. Professor Street criticized the lack of entrenched rights in Britain:

The legal concept of liberty is that there are residual areas . . . where man is frec to act as he likes without being regulated by law... . More than that, in a system like the American, the Constitution is a special law, one that cannot be changed except by a special procedure different from that for ordmary laws. Was it a good thing that all the restraints on freedoin contained in the Official Secrets Act of 1911 were ruslied through the House of Commons in one day in time of peace as if they were matters of no moment, the citizen no doubt unaware of that curtailment of his liberty which was thereby being effected? Parliamentary sovereignty in Britain ensures that Parliament can change any law, however fundamental, by the same process as, say, a law whicli increases the amount whicli a local authority may charge for dustbins.

H. STREET, supra note 22, at 284-85. See supra notes 67-73, 80-83 and accompanymg text. See Atlas, supra note 24, at 36, col. 1 ("To an American, accustomed to the defeuse of individual rights afforded by the Constitution and the Bill of Rights, the power concentrated in the hands of the British Government is extraordinary."). 
A communitarian ideal may work well im a unitary and homogeneous society, but as Britain becomes more pluralistic, it will be forced to rethink its approach to entrenching individual rights against parliamentary abrogation. Historically, British jurisprudence has not been receptive to the idea of rights existing free and clear of parliamentary sanction. Professor Raymond Wacks has noted the problem with this approach: "Our law is manifestly madequate to protect the individual against various attacks made, often in the name of progress, order or hiberty, upon his personality."267

The benefit seeured by the British approach is the certainty with which mdividuals know the parameters of legal sanctions and individual right. 268 However, the use of tradition could provide meaningful guidance in limiting a Britisl right of privacy. ${ }^{269}$ Furthermore, we must question whether we want to value certainty above liberty. ${ }^{270}$ The Britisli systems' reliance on parliamentary reform keeps the system neat and tidy, but it also results in imdividual cases of mjustice. Even though the American approach lacks order, rules, and definition, its flexibility allows for immediate response to individual injustice. Botl systems could benefit from an increased reliance on each society's traditions of liberty to cabin the riglit of privacy.

It may be that privacy is not a pressing social concern because the traditions and habits of British society do not require the legal vindication of such interests. For generations, tradition and social mores operated to guarantee some modicum of personal autonomy. According to Professor Alan Westim, "The Enghisli accomplisl witl reserve what the Germans require doors, walls, and trespass rules to enforce."271 Althougl legal guarantees are not always the ouly way to achieve a desirable social end, they sometimes are the surest means. Enghish society historically has been a small, homogeneous population, witl strong family structure, a class system, public support of the government, and an

267. R. WACKs, supra note 2 , at 21.

268. P. ATTYAH \& R. SUMMERS, supre note 20 , at $133-41$.

269. The jurisprudence of the European Court and the EEC already incorporates the traditions of the western European nations. See supra notes 115-20 (European Court) and 168-70 (EEC) and accoinpanying text; see generally supra notes 227-35 (describing how tradition could provide ineaningful guidance to United States courts).

270. Professor Street observed:

[I] $t$ will be no bad thing for [the reader] to consider whether [Britain is] better off without a constitution, relying on the ordinary Courts to minimize as nuch as is reasonable any specific encroachments on our freedom. Does the practieal, piecenneal improvisation suit us better than the formal high-sounding manifesto? Or do we pay too high a price in more uncertainty about the precise limits of our freedom?

H. STREET, supra note 22, at 11. Street strongly implies that Britain needs to rethink its reliance on parliamentary restraint. Id. at 283-89.

271. A. WESTIN, supra note 252, at 29. 
elite system of education. ${ }^{272}$ Consequently, the force of tradition remains strong in Britain. Granting the validity of these observations, the question of the rights of mdividual minorities is still open. English society is changing, and the social strictures that once were sufficient may no longer suffice to protect liberty. ${ }^{273}$ Minority members of British society must be provided with a procedural means of asserting their autonomy claims against the community of which they are a part. This is the essence of a truly free society.

\section{Conclusion}

Autonomy interests are vindicated against government encroachment, in part, through the legal constraint of privacy riglits. If the British are formalistic and miserly in conferring privacy riglits on individuals, then Americans are imprecise to the point of absurdity in defining an individual's privacy rights. Taken to its logical extreine, a "right to be let alone" ultimately is the right to be ungoverned.274 No orderly society could survive the recognition of such an absolute riglit of privacy. The extent to which a community will tolerate deviant beliavior inust ultimately be related to the maintenance of a sense of well being in the community. If the use of illicit drugs, or abuse of women or children, were claimed as privacy rights, then the accompanying disquietude visited upon the community would rend the social fabric asunder. The existence of a social compact caimot be squared with absolute individual autonomy. Conversely, however, the demands of the cominunity cannot unduly impinge on the individual's ability to be self-defining-at least in sone respects. Thus the proper ineasuring stick for the effectiveness of any governmental regime is the extent to which personal hiberty is maximized in a given nation. Both the United States and Great Britain lave had relative successes and relative failures in their approaches to the protection of privacy.

The problein that any government faces is one of drawing lines between competimg interests-those of the cominunity in regulating and defining itself through custoni and law, and that of the individual in maintaining vital elenents of personality and self. Although this prob-

272. See id. at 26.

273. As one contemporary British writer noted:

The old British complacency [regarding the lack of a written constitution] may never have been justified. Today, it is clearly quite unjustified. . . . What is needed, if only somebody can find the recipe, is a charter of rights that entrenches our liberties without suggesting that everything worth having must somehow be among them.

Ryan, supra note 56 , at 8 , cols. $1-2$.

274. Schneider, State-Interest Analysis in Fourteenth Amendment "Privacy" Law: An Essay on the Constitutionalization of Social Issues, LAW \& CoNTEMP. ProBS., Winter 1988, at 79, 86-87. 
lem does not lend itself to a simple and precise answer, community traditions of individual liberty are a safe starting point. The closing paragraph from one of the minority reports filed by the Younger Committee summarizes the interests motivating the discussion of the legal and social necessity of privacy rights, and provides a fitting conclusion:

Somehow I find all the excuses [by the majority for rejecting a general right of privacy] inadequate. I prefer a society where a zeal for truth is matched by compassion and where even the weakest of our fellow citizens knows that he can call upon the law in his unequal fight with those powerful interests, including the government, who abuse his freedom. ${ }^{275}$

The protection a society affords individual autonomy reflects whether it is truly free; citizens should remain ever vigilant, lest they find their government ommipresent.

Ronald J. Krotoszynski, Jr.

275. YoUNGER REPORT, supra note 15, at 212 (minority report of A. W. Lyon). It is my hope that this Note helps provide a technical understanding of the role of privacy law in Britain, and also, through a comparison with U.S. privacy law, some insight into the systemic differences that exist between the two nations. More fundamentally, however, I hope that the tension which exists between governance and autonomy is made clear, for it is the agon between self and commumity which drives privacy law. Where and how to draw lines respecting legitimate claims of autonomy is beyond my abilities. Let it suffice to say that communities, pohticians, and most importantly judges, must draw this line on a daily basis. However, I do believe that courts should consider a commumity's traditions of deference to individual decision-1naking when citizens challenge government regulations of their daily hives. In balancing the autonomy of the individual against the needs of the community, the tenor of the polis is struck; thus, the act is a delicate one whose repercussions will have real affects on both the community and the individual. 